\title{
The problems of the post-Cenomanian tectonic evolution of the central parts of the Sredna Gora Zone. The wrench tectonics - how real is real?
}

\author{
Alexandre Kounov ${ }^{1}$, Ianko Gerdjikov² \\ ${ }^{1}$ Department of Environmental Sciences, Basel University, 4056 Basel, Switzerland; e-mail: a.kounov@unibas.ch \\ ${ }^{2}$ Faculty of Geology and Geography, Sofia University "St Kliment Ohridski", 1513 Sofia, Bulgaria; \\ e-mail: ian.gerdjikov@gmail.com
}

(Accepted in revised form: August, 2020)

\begin{abstract}
The Sredna Gora Zone holds a unique place in the tectonic subdivisions of the Balkanide orogen and its evolution is still a subject of debate. In the last twenty years, the idea of strike-slip-related evolution of the zone has been invoked. However, for the moment, the number of thorough studies where such a scenario is envisaged is limited, and substantial evidence based on detailed fieldwork is still missing. In this article, we discuss some of the major problems of the suggested wrench tectonic concept in the evolution of the central part of the Sredna Gora Zone. These are the character of some major shear zones in the area, to which strikeslip movements are attributed, and the transtension-transpression evolution scenario for the Chelopech and Panagyurishte basins. Despite refuting completely their wrench tectonic-related evolution, we confirm the presence of strike-slip and oblique slip structures cutting the sediments, whereas the time of their activity and role in the deformation of the basin fill are yet to be revealed. Finally, we present a model based on natural examples and analogue modeling, in which the long-lived dextral Maritsa shear zone represents a zone of localized strain partitioning, separating the opposite vergent thrust belts of the Rhodope to the south and the Sredna Gora and Balkan fold-thrust belt to the north, during oblique or possibly orthogonal convergence.
\end{abstract}

Kounov, A., Gerdjikov, I. 2020. The problems of the post-Cenomanian tectonic evolution of the central parts of Sredna Gora Zone. The wrench tectonics - how real is real?. Geologica Balcanica 49 (2), 39-58.

Keywords: Sredna Gora Zone, Chelopech and Panagyurishte basins, Maritsa fault zone, half graben, strain partitioning.

\section{INTRODUCTION}

The Sredna Gora Zone holds a special place in the tectonic subdivisions of the Balkanide orogen because it represents a Late Cretaceous magmatic arc and intra-arc basin, often crosscutting former major tectonic boundaries (Fig. 1; e.g., Boccaletti et al., 1974; Aiello et al., 1977; Nachev, 1978; von Quadt et al., 2005). This is probably why it has always been difficult to define clearly its tectonic boundaries (e.g., Ivanov, 2017). In the last twenty years, a large number of studies have been dedicated to the magmatism along the zone, while its tectonic evolution still remains poorly constrained. Early studies on its tectonics (e.g., Bončev, 1940; Karagjuleva et al., 1974) have already established the existence of a Late Cretaceous extensional phase associated with the opening of the arc related basin(s), followed by compression, all part of the Alpine orogeny. The main structures have been described as thrust and reverse faults associated with the formation of antiand synforms in the Upper Cretaceous sediments (e.g., Karagjuleva et al., 1974).

Ivanov (1998) first launched the idea of the importance of wrench tectonics in the evolution of the Sredna Gora Zone. Consequently, in several oral presentations and conference abstracts, he developed his ideas about the transpressive deformation in the zone, redefining most of the major thrust and reverse faults as strike-slip faults (e.g., Ivanov et al., 2001, 2002, 2004; Ivanov and Dimov, 2002). Although accepted by many of our colleagues without the necessary criticism and scientific rigor, these ideas have never been 
openly and thoroughly discussed. Instead, most of the studies from this area ended up only as short conference abstracts or unpublished reports, often not available to the scientific community. The only exceptions are several studies combining detailed structural and AMS (anisotropy of magnetic susceptibility) analyses on several Late Cretaceous magmatic bodies along the Maritsa shear zone (Fig. 2; Georgiev et al., 2009, 2014; Henry et al., 2012; Naydenov et al., 2013).

Indeed, the concepts of tectonic evolution of the central parts of the Sredna Gora Zone were influenced also by the studies of Doglioni et al. (1996) and Vangelov et al. (2013), who presented a transtension-transpressional model for the Alpine evolution in the Eastern Balkan Zone (Fig. 1). Here we must mention also the paleostress analysis of Bergerat et al. (2010) acknowledging the existence of strike-slip faulting regimes in the evolution also of the eastern Sredna Gora Zone (northeast of Stara Zagora, Fig. 1). However, these studies lie out of the area and the scope of our study, and therefore will not be further discussed.

The Late Cretaceous sediments in the central part of the Sredna Gora Zone, cropping out in the Chelopech and Panagyurishte sedimentary strips, have been often described as pull-apart basins formed during active transtension and closed under transpression (Fig. 2; e.g., Antonov and Jelev, 2001; Jelev et al., 2003; Chambefort and Moritz, 2006). Unfortunately, these studies do not provide detailed structural data or the so-important sedimentary facies analysis supporting such a scenario, and hence do not offer a plausible model of their presumably strike-slip-related evolution.

Highly regrettable is also the fact that these concepts, unsupported by solid research, penetrated several review papers on the evolution of the Apuseni-Banat-Timok-Sredna Gora magmatic belt (Fig. 1; e.g., von Quadt et al., 2005; Zimmerman et al., 2008; Gallhofer et al., 2015) and have gained international recognition. Unfortunately, these ideas have also been embraced by the geological teams of mining companies in the area. Several important porphyry copper and polymetallic vein deposits are presently mined in the central part of the Sredna Gora Zone (Fig. 2; Elatsi, Chelopech, Asarel), and this will undoubtedly influence the strategies for further exploration. An example of such is a scientific report of the US Geological Survey (Drew, 2005), where the strike-slip tectonic model for the Bulgarian part of the Apuseni-Banat-Timok-Sredna Gora magmatic belt is based only on a conference abstract of Ivanov et al. (2000) and further suppositional constructions.
Over time, we have accumulated a lot of observations and knowledge along this particular area, which we would like to share now with the geological scientific community. In this article, we discuss some of the problems of the wrench tectonics concept for the evolution of the central Sredna Gora Zone. This includes some of the major tectonic features, to which the strike-slip character was attributed, as well as the evolution of the Late Cretaceous basins. Finally, we present an alternative model for the evolution of the area, which we believe better fits the regional tectonic frame.

\section{SHORT GEOLOGICAL BACKGROUND}

At present, it is largely accepted that the Sredna Gora Zone in Bulgaria represents part of a large Late Cretaceous magmatic belt, which can be followed from the Apuseni Mountains to the Black Sea (Fig. 1), formed above the subducting to the north, below the European plate, Neotethys slab (e.g., Boccaletti et al., 1974; Gallhofer et al., 2015). The magmatic activity was coeval with the formation of several volcano-sedimentary basins, or possibly one large basin with several depocenters, filled with Cenomanian to Maastrichtian deposits (e.g., Dabovski et al., 2009; Ivanov, 2017). At present, in Bulgaria, the Upper Cretaceous sediments crop out in four distinct areas: Sofia, Panagyurishte, Stara Zagora, and Burgas (Fig. 1). In the central part of the zone, the folded and thrust sequences form three relatively narrow tectonic slivers named Chelopech, Panagyurishte, and Stara Zagora strips (Figs 1, 2; e.g., Dabovski et al., 2009; Ivanov, 2017).

The Sredna Gora Zone was also involved in two major Alpine (post-Triassic) compressional phases. During the first one, the Early Alpine phase (Late Jurassic-Early Cretaceous), the whole zone, together with the Balkan Zone to the north, was involved in the closure of the Triassic-Early Cretaceous basin and north-vergent thrusting along the Balkan fold-thrust belt (e.g., Vangelov et al., 2013). During the second compressional phase, the Late Alpine (Late Cretaceous-Paleogene), Late Cretaceous basins were closed and deformed again along the northvergent thrust and reverse faults (e.g., Bonchev 1940). The translations were apparently smaller, compared to the first phase, varying in amplitude and character at different places along the orogen (Vangelov et al., 2013). For example, farther to the west in the Southern Carpathians, more extensive translations have been recorded compared 
to the Balkan fold-thrust belt (e.g., Schmid et al., 2008). The continuation of the Sredna Gora Zone there (i.e., the Getic unit) in fact represents a far-traveled nappe sheet confined between the Supragetic (above) and Danubian (below) nappes (Fig. 1).
The following Cenozoic evolution of the zone is not well constrained. It was a region of at least two extensional phases related to the formation of continental to marine late Eocene-Oligocene and Neogene-Quaternary basins (e.g., Burchfiel et al., 2008; Kounov et al., 2018).

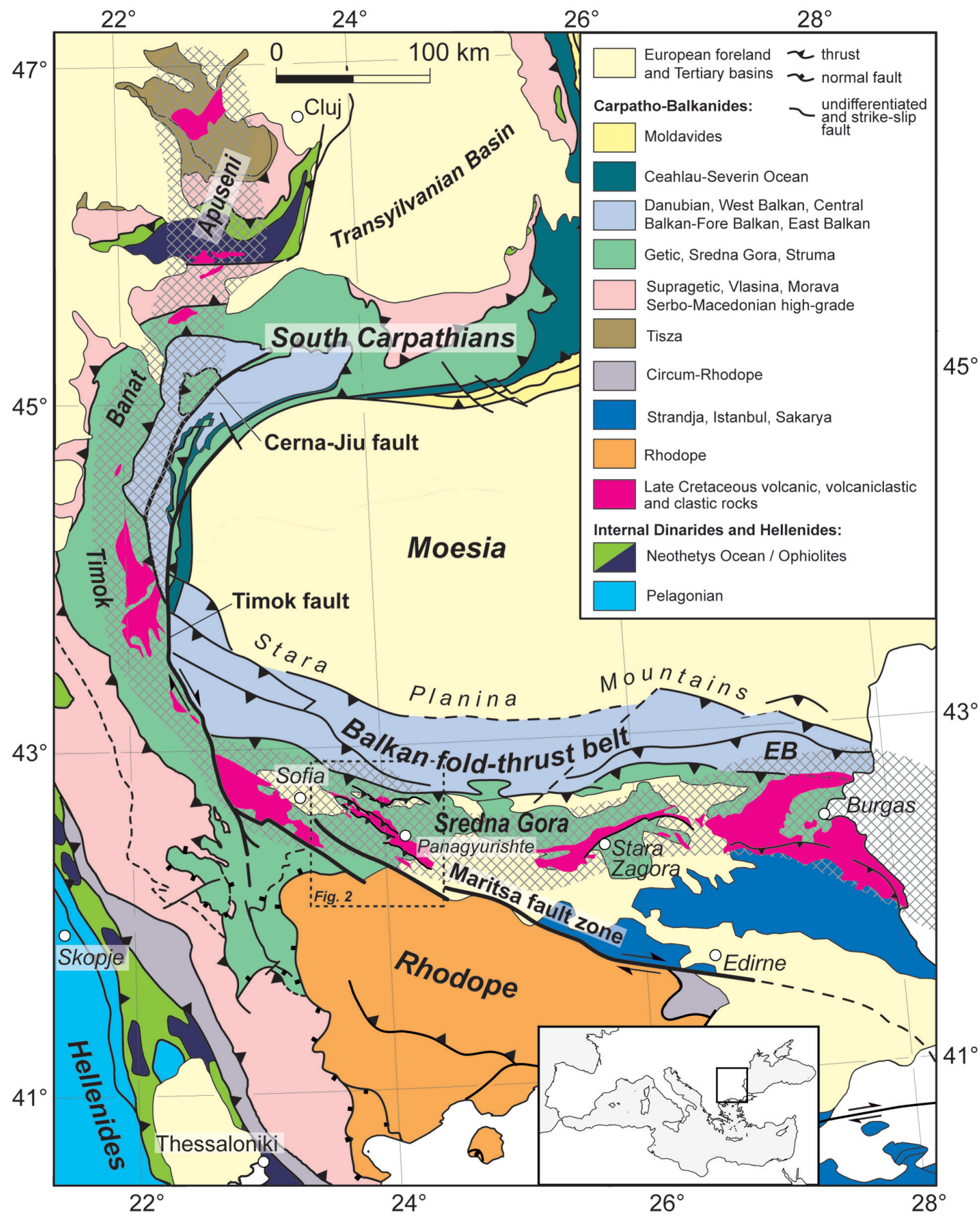

Fig. 1. Tectonic map of the central part of the Balkan Peninsula (modified after Schmid et al., 2008) showing major tectonic units and the occurrences of Late Cretaceous volcaniclastic basins from the Apuseni-Banat-Timok-Sredna Gora belt (shaded area). The box outlines Fig. 2. EB - East Balkan Zone. 


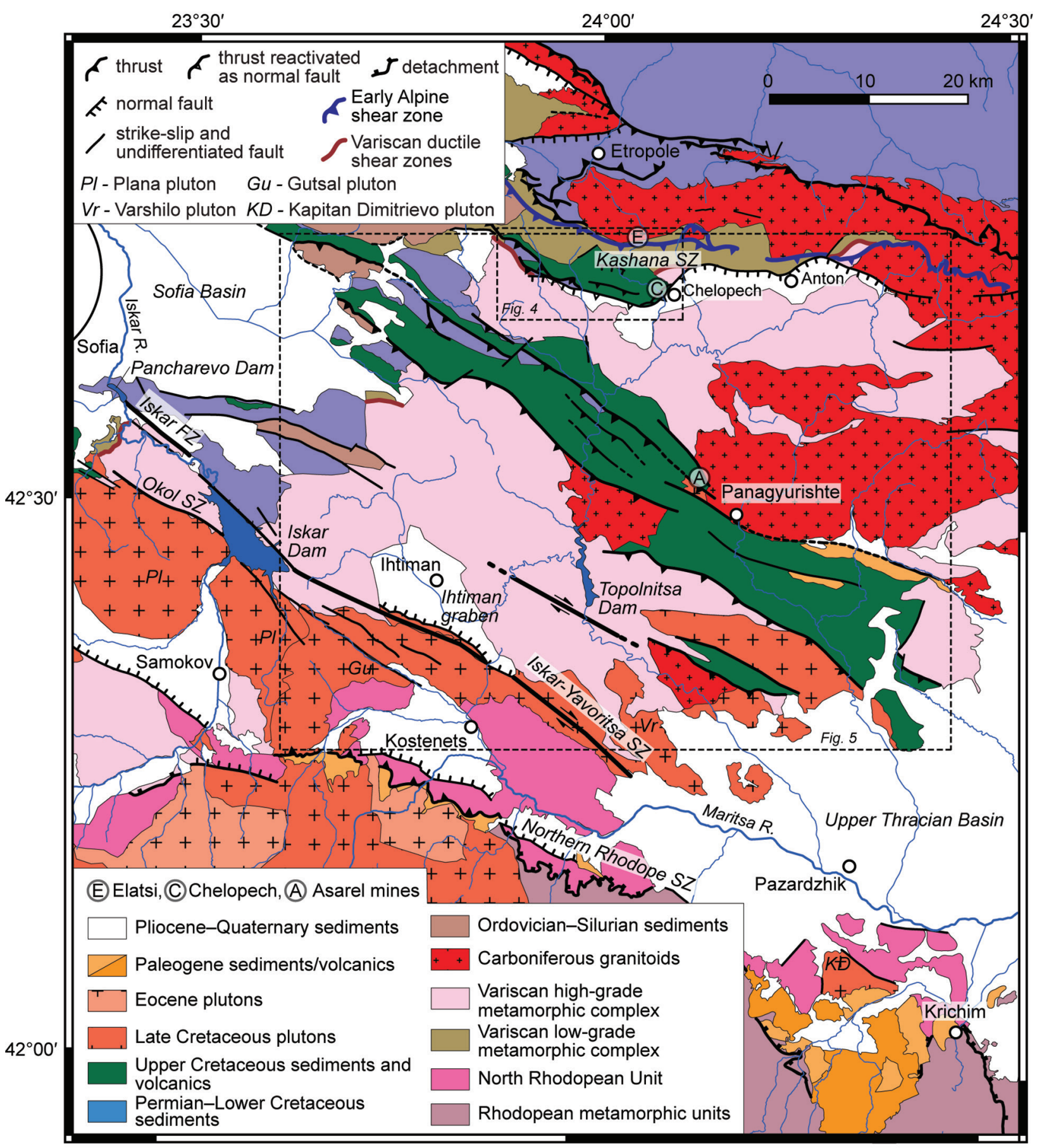

Fig. 2. Geological map of part of the central Sredna Gora Zone, with major fault structures. The boxes outline Figs 4, 5.

\section{MAJOR REGIONAL TECTONIC ZONES}

Herein, we discuss the major tectonic zones from the central part of the Sredna Gora Zone, to which a strike-slip character has been attributed at certain stages of their evolution. Other important structures, related to the deformation of the Upper Cretaceous sediments in the area, are discussed further below.

\section{Maritsa fault zone}

The Maritsa fault zone was introduced for the first time by Bonchev (1946) as a major lineament separating the Rhodope from the rest of the Balkanides, whereas its strike-slip character was later proposed by Ivanov et al. (1989). The Maritsa fault zone is indeed considered as one of the major tectonic fea- 
tures in the eastern part of the Balkan Peninsula, which can be traced from the area of Sofia to Edirne (Fig. 1) and which is characterized by its longevity (e.g., Bonchev, 1946). Careful examination of studies dedicated to this zone clearly shows that the existence of such a continuous regional tectonic structure has never been clearly established. Instead, many different in their character, age and extent shear zones and brittle faults have been described. However, it must be noted that this zone remains the only tectonic structure in the Sredna Gora Zone where a strike-slip character is confidently recognized. Below, we make a short review of the studies on different segments along the eastern part of the zone, which has direct connection to the present discussion.

\section{Iskar-Yavoritsa fault zone}

This structure was first described by Dimitrov, (1937) as a steep fault zone along the Iskar River Valley (SE of Sofia, Fig. 2), where it was later further extended to the Pazardzhik area by Boyadjiev (1971) who named it the Iskar-Yavornishki fault zone. In fact, despite a map-view spatial continuity with similar kinematics along the whole zone, it can be considered as two distinct segments. The one studied in more detail, traced from the Iskar Dam to the Upper Thracian Basin, was later described as the Iskar-Yavoritsa ductile shear zone (Iskar-Yavoritsa SZ on Fig. 2; Georgiev et al., 2009). Georgiev et al. (2009) presented structural and AMS data suggesting that dextral strike-slip movements along the zone controlled the syntectonic emplacement of Late Cretaceous (86-75 Ma) granitic plutons. Field data and those obtained from the AMS analysis reveal that lineations generally plunge towards the NW at moderate angles, suggesting that the dextral shearing had a large vertical component. Similar results were reported also by Henry et al. (2012) for the Kapitan-Dimitrievo pluton northwest of Krichim (Fig. 2), although a particular shear zone in the area was not described. Later, Georgiev et al. (2014) presented structural and AMS studies from another Late Cretaceous pluton situated along the Maritsa fault zone (Plana pluton, Fig. 2), showing that its emplacement was spatially and temporally related to another subvertical shear zone (the Okol shear zone, Fig. 2) characterized by vertical movement. All these studies suggest a transpressional tectonic regime related to dextral shearing along the IskarYavoritsa zone and the syn-kinematic emplacement of the granites between $86 \mathrm{Ma}$ and $78 \mathrm{Ma}$. Such a suggestion requires some strain partitioning between the transpressive Iskar-Yavoritsa shear zone and the extensional basins to the north, which at that time experienced thermal subsidence during the early post-rift stage (Bergerat et al., 2010).

The second segment, traced between Sofia (area of Pancharevo Dam) and the Iskar Dam, is known as the Iskar fault zone (Fig. 2). It is a brittle dextral fault zone that may be the northeast prolongation of the Late Cretaceous Iskar-Yavoritsa ductile shear zones. However, the entirely brittle character of shearing and its supposed Paleogene age (Gerdjikov et al., 2015) suggest that the zone could represent an independent segment of the Maritsa fault system.

\section{North Rhodopean Unit}

This unit includes high-grade metamorphic rocks cropping out in the northernmost slopes of the Rhodope Mountains along the Maritsa River Valley (Ivanov et al., 1989; Ivanov, 2017). The North Rhodopean Unit is the northernmost tectonic element of the Rhodope metamorphic complex, situated between the Northern Rhodope shear zone (Gerdjikov and Gautier, 2006) and the Iskar-Yavoritsa shear zone (Fig. 2). The penetrative ductile fabric records a dextral strike-slip sense of shear (Ivanov et al., 1989; Naydenov et al., 2013). Naydenov et al. (2013) presented detailed structural studies, combined with U-Pb datings (from the area between Kostenets and Krichim, Fig. 2) from a part of the Maritsa shear zone, suggesting prolonged synmetamorphic evolution (from $\sim 130$ Ma to $\sim 78 \mathrm{Ma}$ ). It must be noted that, in some studies (Sarov, 2006; Naydenov et al., 2013), the North Rhodopean Unit is regarded as a part of the newly introduced Thracian lithotectonic unit.

\section{Shear zones in the Sredna Gora Variscan basement}

North of the Iskar-Yavoritsa shear zone, within the Variscan high-grade metamorphic complex of the Sredna Gora Zone, several sub-parallel NWSE trending brittle faults have been identified (e.g., Iliev and Katskov, 1993). In the area of the Topolnitsa Dam, along one of these zones, Bonev (1996) described ductile sub-vertical mylonites bearing sub-horizontal lineations and showing dextral sense of shear (Fig. 2). Later, Velichkova et al. (2004) reported muscovite and biotite ${ }^{40} \mathrm{Ar} /{ }^{39} \mathrm{Ar}$ ages between $105 \mathrm{Ma}$ and $99 \mathrm{Ma}$ from these zones, interpreted as the age of the shearing. These ${ }^{40} \mathrm{Ar} /{ }^{39} \mathrm{Ar}$ data are very important as they are suggesting ductile deformation in the area of the Maritsa fault zone at the boundary between the Early and Late Cretaceous. 


\section{Kashana shear zone and the problem of the Late Cretaceous magma emplacement}

After the first detailed works along the Zlatitsa part of the Stara Planina Mountains, an approximately E-W trending, north-vergent Alpine fault zone was recognized (Kouikin et al., 1971; Antonov, 1976). The zone was called the Kashana thrust and was regarded as the main tectonic boundary in the central parts of the Balkan fold-thrust belt, separating the Balkan units from the Sredna Gora Zone (Fig. 2; Ivanov, 1998, 2017; Antonov et al., 2010). Later, this tectonic zone was reinterpreted as a dextral strike-slip fault connecting isolated north-vergent thrust segments (Ivanov et al., 2004; Petrov, 2005a, b; Petrov and Nedkova, 2011). Although this interpretation was based mainly on studies in the Elatsite open pit mine, it was suggested that the zone controlled not only the Late Cretaceous magma emplacement in the area but also the Chelopech Basin formation (e.g., Ivanov et al., 2004).

In several conference abstracts, unpublished reports and papers (Ivanov et al., 2004; Petrov, 2005a, b; Petrov and Nedkova, 2011), the steeply dipping set of NW-SE oriented dextral (named R-shears) and NE-SW oriented sinistral (named R'-shears) strike-slip faults, together with generally subequatorial dextral strike-slip faults (named P-shears) observed in the Elatsite open-pit mine (Fig. 3a), were associated with the NE-SW trending Kashana shear zone. Although the cited above publications do not

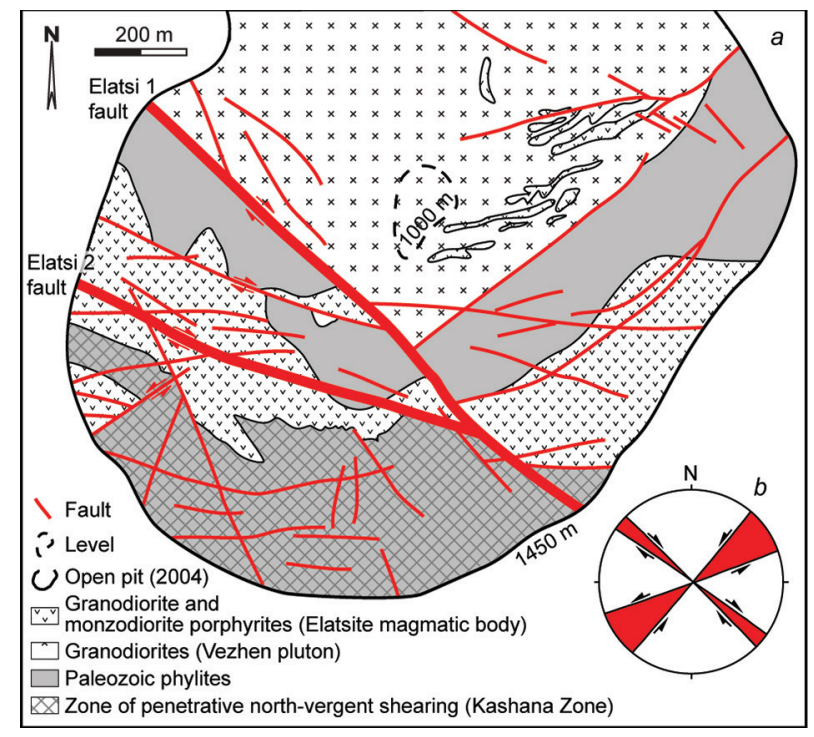

Fig. 3. a) Geological map of the Elatsite mine open pit with traces of the fault structures (modified after Petrov, 2005, and Cotesta, 2015). b) Rose diagram of the conjugate fault sets in the mine pit as described by Petrov (2005). present any diagrams and other schemas with the orientation of the described structures, if we consider the given by Petrov (2005a) azimuths for the presented as conjugated R-shears fault sets $\left(125^{\circ}-\right.$ $135^{\circ}$ for the NW-SE oriented dextral and $40^{\circ}-70^{\circ}$ for the NE-SW oriented sinistral strike-slip faults; Fig. $3 b$ ), it becomes clear that the proposed model is wrong. The above azimuths show that the bisector of the acute angle between the fault sets is rather E-W oriented (Fig. $3 b$ ), and therefore they could not represent a conjugate pair of R-shears. Given their sense of movement, such a pair of conjugate fault sets must have a N-S oriented bisector of the acute angle, which would coincide with the maximum stress axis (Twiss and Moores, 2001) and consequently the P-shear faults would not have the subequatorial orientation as presented above.

Although all these faults cut the magmatic bodies in the mine pit, relative parallelism of some of the faults with these dykes and small stocks allowed Petrov (2005b) to suggest that the described structures controlled the Late Cretaceous magma emplacement under a general transpressional regime. On the other hand, Handler et al. (2004) relate the magma emplacement to a general N-S extension, evidenced by the subequatorial trend of the observed in the mine dykes and veins. Additionally, Georgiev (2004) suggested that the Elatsite magmatic body was simply emplaced in the space between the southern contact of the Carboniferous Vezhen pluton and the south-dipping Kashana thrust zone (Fig. 3a).

There are now several studies (e.g., Gerdjikov and Georgiev, 2005, 2006a; Lazarova et al., 2006; Nanov et al., 2016) that have clearly proved that this zone has the characteristics of a generally lowgrade, brittle-ductile to ductile, thrust fault, which was most probably active during the Early Cretaceous (Fig. 2). It is well traced now along the southern border of the mine pit, where it is represented by a brittle-ductile shallow, dipping to the south, wide shear zone, developed entirely in the Paleozoic phyllites (Figs 2, 3a, 4; Georgiev, 2004, 2008), and where it is cut by the later steeply dipping strike-slip faults and Late Cretaceous magmatic rocks (Nanov et al., 2018).

\section{THE BASINS}

East of Sofia, in the central part of the Sredna Gora Zone, two slivers of folded and imbricated Upper Cretaceous sediments are named the Chelopech and Panagyurishte strips (e.g., Dabovski et al., 2009; Ivanov, 2017). In reality, they represent remnants of 
basins filled with mainly marine sediments and volcaniclastics, which were probably part of one and the same large basin during the post-rifting period of its evolution. Therefore, further in the discussion, we will refer to them as basins (Fig. 2). Below, we tackle the proposed transtensional-transpressional theory for the evolution of these basins, confronting it against the field evidence and simple geological logic.

\section{Pull-apart versus half-graben basins}

\section{Structural characteristics}

Although there are several papers where the pullapart character of the Chelopech and Panagyurishte basins is mentioned (e.g., Chambefort and Moritz, 2006, 2014; Georgiev et al., 2009; Gallhofer et al., 2015; Vangelov et al., 2019), there are none where direct structural evidence based on field observations for such an evolution is presented. Only the study of Jelev et al. (2003) suggested, for the Chelopech Basin, that its pull-apart evolution was controlled by strike-slip movements along the so-called Sub-Balkan deep-seated fault (Bončev, 1961). The latter is an unproved structure introduced by Bončev (1961), encompassing contrasting by their character and time of their activities faults described along the southern slope of the Stara Planina Mountains. Its proposed manifestation today includes the subequa- torial normal faults developed along the southern slope of the Stara Planina Mountains, bordering the Chelopech Basin to the SSW and SE (Fig. 4). Jelev et al. (2003) present neither structural observations and analysis nor any figures, and therefore we can conclude that the presented pull-apart basin evolution model is based mainly on hypothetical constructions.

We suspect that the idea for a pull-apart character of both basins originates from the shape of the cropping-out remnants of Upper Cretaceous sediments in the area, as well as from the orientation of the tectonic structures bordering them (Figs 2, 4, 5). It is true that they represent near rhomboidal, generally NW-SE elongated, strips, but this is their only resemblance with pull-apart basins.

Most of the faults bounding the present-day remnants of the Upper Cretaceous sediments in the central part of the Sredna Gora Zone are reverse to thrust faults and later normal faults, which strongly suggests that the present-day shape of the basins is related mainly to their deformation during their inversion and later extensional evolution. The particular rhomb-like shape of the SE margin of the Chelopech Basin is simply due to the existence of reverse to thrust faults, oblique to the basin elongation, partially reactivated as normal faults (Fig. 4). Also important is the fact that the NE boards of the Chelopech and Panagyurishte basins are generally not fault-bounded (Fig. 2, e.g.; Iliev and Katskov, 1990; Vangelov

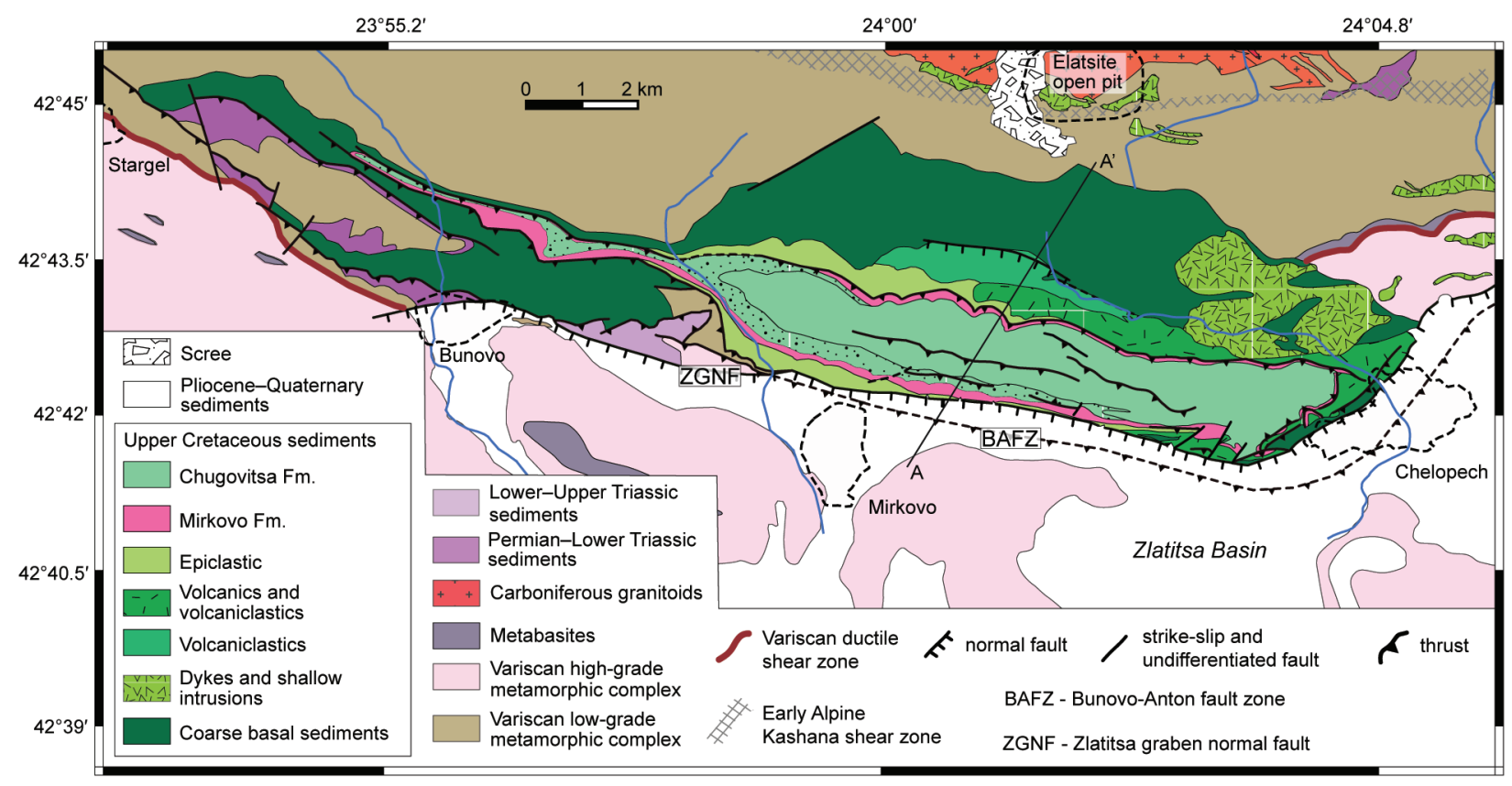

Fig. 4. Geological map of the Chelopech Basin with major fault structures (modified after Antonov et al., 2010, and Angelov et al., 2010). 


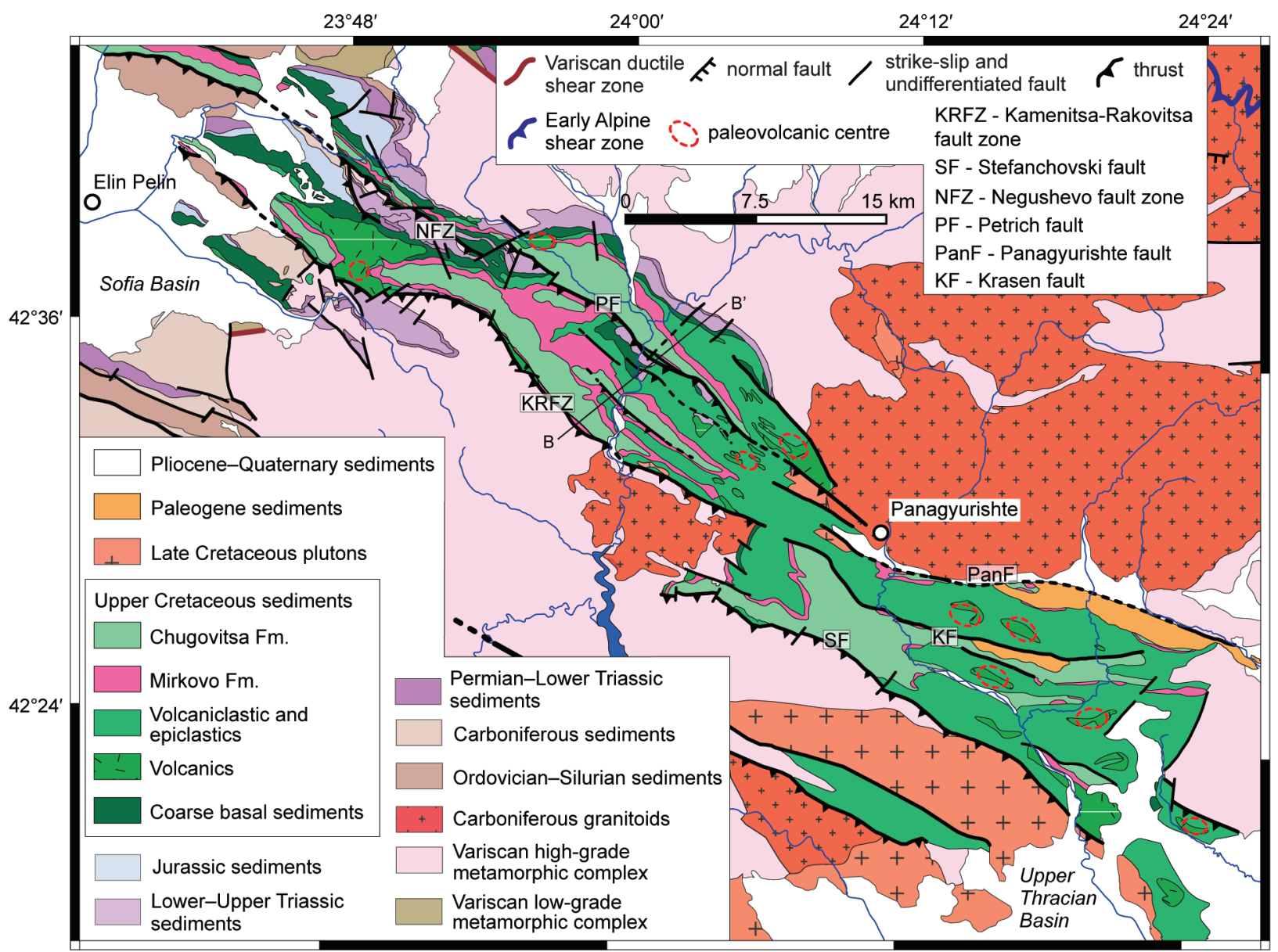

Figure 5. Geological map of the Panagyurishte Basin with major fault structures (modified after Iliev and Katskov, 1990).

et al., 2019). Interestingly, the NW terminations of both basins wedge out below several reverse fault structures (Figs 2, 4, 5). Another fact incompatible with pull-apart basin evolution is the striking absence of any diagonal (cross-basin) fault structures typical for strike-slip type basins (e.g., Wu et al., 2009). We, therefore, conclude that the structure of these basins clearly does not present any structural characteristics of pull-apart or any other type of strike-slip basin. Moreover, strike-slip and sidewall extensional faults along the basin boundaries (e.g., Wu et al., 2009), which would control its evolution, were not recognized.

Of course, extensional non-reactivated structures from the early rifting period of the evolution of both basins are probably not well preserved. The only structures, which, for the moment, can be attributed to the rifting period, are segmented synsedimentary normal faults observed mostly along the NNE margin of the Chelopech Basin (Figs 4, 6). Unfortunately, the existence of such structures along the opposite SSW margin of the basin could not be proven because this part has been strongly eroded and/or disintegrated by the compressional and later extensional structures (Figs 4, 6). Nevertheless, the existence of normal faults parallel to the basin margin is rather suggestive of an extensional graben character. Diagonal extensional structures, so typical for strike-slip-related pull-apart basins, or en-échelon extensional faults along its margin, characteristic for the transtensional basins (e.g., Wu et al., 2009), were not observed.

The deformation of the basin's fill is related to NW-SE trending thrust and reverse faults (Figs 4-7). Their steep, to the SW, dip could be because they represent inverted normal faults related to the rifting period (Figs 6, 7). It is important to notice that these NE-vergent reverse faults are developed mostly along the SW margin of the former basins (Figs 2, 4-7), which is more compatible with the reactivation of half-graben structures rather than pull-apart basin.

Unfortunately, the appropriate structural and paleostress analyses regarding strike-slip faults in 


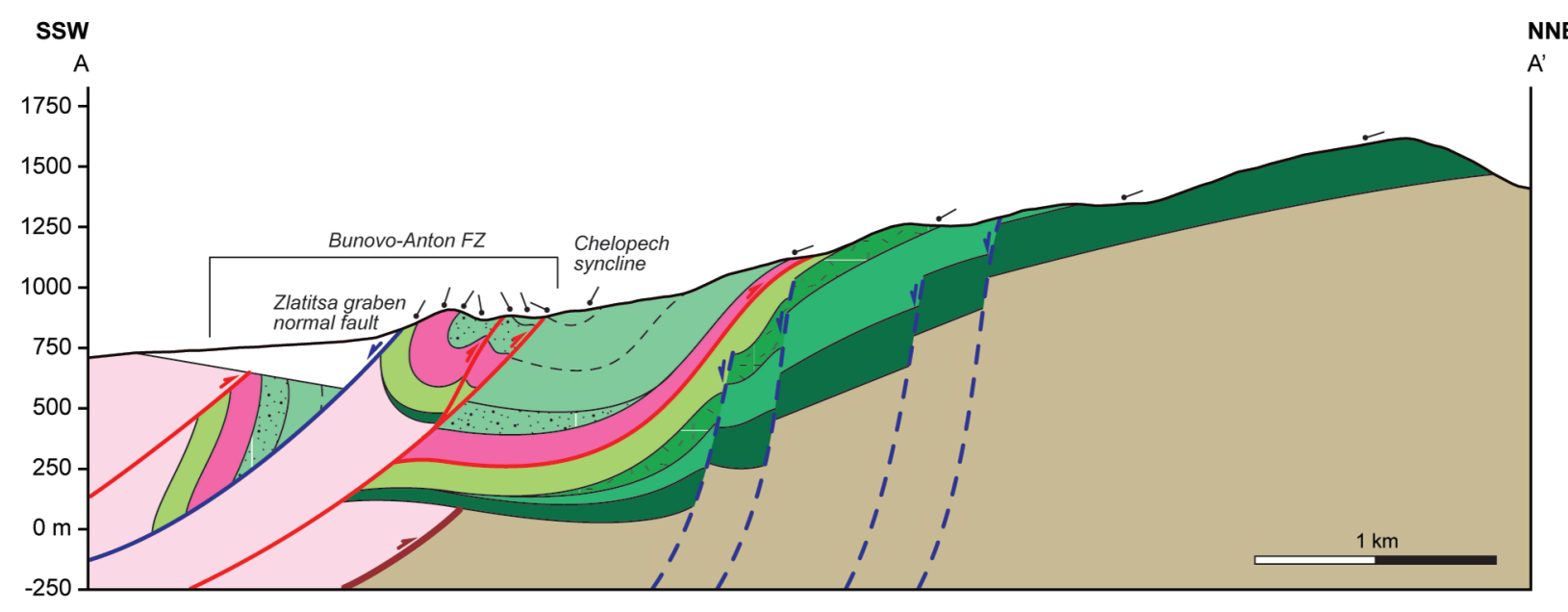

Fig. 6. Interpretative profile through the Chelopech Basin based on surface observations. For location, see Fig. 4 trace AA'. Lithological key as in Fig. 4. Scale $\mathrm{V}=\mathrm{H}$.

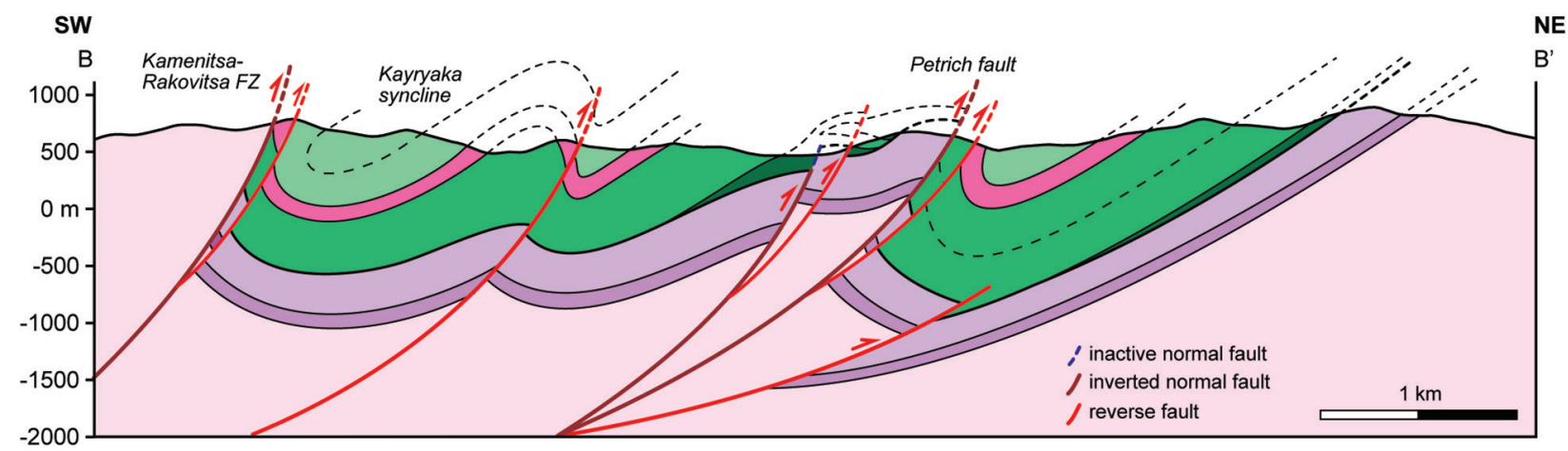

Fig. 7. Interpretative profile through the Panagyurishte Basin based on surface observations. For location, see Fig. 5 trace BB'. Lithological key as in Fig. 5. Scale V = H.

both basins mentioned in several papers (e.g., Antonov and Moev, 1978; Jelev et al., 2003; Chambefort and Moritz, 2006) are non-existent. Our observations clearly show that the strike-slip fault structures cut not only the Upper Cretaceous sediments but also most other structures (reverse and normal faults). This clearly shows that they have nothing in common with the opening of the basins and their syn-rift evolution.

\section{Sedimentary facies distribution}

It is true that tectonic structures related to the extensional stage of basin evolution are often poorly preserved due to the consequent inversion tectonics, and therefore their recognition and interpretation remain challenging. However, the sedimentary facies distribution is often better preserved and represents, together with the evolution of the depocent- ers, sound evidence for the style of the basin evolution (e.g., Nilson and Sylvester, 1995; Noda, 2013). Strike-slip basins, for example, are characterized by lateral migration of the depocenters in the same directions as source terranes along the principal displacement zones and generally opposite of the direction of axial sediment transport (e.g., Nilson and Sylvester, 1995; Noda, 2013). Unfortunately, studies dedicated to facies evolution and distribution in both basins are still missing; nevertheless, a careful examination of the available geological maps (Iliev and Katskov, 1990; Antonov et al., 2010) gives some basic information on the evolution. Herein, we report a total lack of sedimentary properties indicative of pull-apart or any other type of strikeslip basin evolution. The coarse basal sediments are deposited mainly along the northern margins of both basins, or next to inverted normal faults in the middle of the basin (e.g., Panagyurishte basin), and 
are rare or completely missing along their southern board (Figs 4-7). This distribution is more compatible with the formation of half-grabens in the evolution of the basin.

Another characteristic of pull-apart basins is their large stratigraphic thickness relative to the basin size (e.g., Hempton and Dunne, 1984; Gürbüz, 2010). Empirical linear relationship between the basin length and depth is suggested as a direct consequence of the amount of the master fault displacement (Rodgers, 1980), based on the data from ancient and modern pull-apart basins (e.g., Hempton and Dunne, 1984). The maximum lengths of the Chelopech and Panagyurishte basins are about $25 \mathrm{~km}$ and $80 \mathrm{~km}$, respectively (Figs 2, 4, 5). Therefore, according to the above-mentioned relationship, if they were pull-apart basins, the sedimentary thickness should be of at least $2 \mathrm{~km}$ for the Chelopech and between $5 \mathrm{~km}$ and $7 \mathrm{~km}$ for the Panagyurishte Basin (Hempton and Dunne, 1984). The estimated thicknesses for these basins are far from these numbers, especially for the Panagyurishte Basin, with a maximum sediment thickness of not more than $2 \mathrm{~km}$ (Iliev and Katskov, 1990). There is clear evidence that the maximum thicknesses measured today in both basins are close to the real values reached during their evolution. Firstly, the basin fill presents the whole cycle characteristic of the extensional basins, from the syn-rift coarse deposits to the post-rift, related to the thermal subsidence, carbonate Mirkovo and turbiditic Chugovitsa formations, which suggest that probably not much of the sedimentary succession is missing. The transition from fine-grained distal turbidites towards coarser and more shallow-water sedimentation upward in the Chugovitsa Formation is a testimony to the beginning of the inversion in the basin(s) (Vangelov et al., 2019). Secondly, the Maastrichtian sediments of the Chugovitsa Formation are unconformably overlain by continental Danian (Zagorchev et al., 2001) deposits, which leave relatively little time for substantial erosion of the Upper Cretaceous succession.

The only modern study from the area under discussion, containing detailed sedimentological data, is that of Vangelov et al. (2019), who described four stratigraphic logs from the middle of the Panagyurishte Basin. The difference in the basal units in the sections from the hanging wall of the Petrich fault and those from the NE unfaulted border of the Panagyurishte Basin (Fig. 5) are noticeable. Along the hanging wall of the Petrich fault, the sequence begins with thick, coarse clastic sediments, deposited probably along the active normal fault, which was later inverted during compression (Fig. 7), while, along the NE non-faulted border of the basin, the sedimentation starts directly with marine sedimentation. This fact suggests that the NE border of the basin was probably not tectonically active during the evolution of the basin, which is incompatible with pull-apart basin evolution (Fig. 7). Upward, the sedimentation in the basin shows some vertical and lateral changes, which were controlled by the formation and the evolution of several volcanic centers (Fig. 5). Therefore, we conclude that the evolution of the basin was controlled by NW-SE trending, dipping to the SW, normal faults, which were later reactivated as reverse faults during the inversion and the deformation of the basin fill (Figs 5, 7).

\section{Transpression versus compression during the closure of the basins}

Deformation in the Chelopech and Panagyurishte basins is discussed in several papers (e.g., Karagjuleva et al., 1974; Antonov and Moev, 1978; Popov and Mutafchiev, 1980; Dotseva et al., 2016; Gerdjikov et al., 2019; Gerdjikov et al., in press). In a few of them, its transpressive character is evoked (Antonov and Jelev, 2001; Chambefort and Moritz, 2006; Balkanska et al., 2018), as some of the thrust and reverse fault structures were reinterpreted as strike-slip faults. Due to the fact that there are several differences in the structures related to the deformation of both basins, we will discuss them separately.

\section{Chelopech Basin}

This basin is relatively better studied than the Panagyurishte Basin, thanks to the presence of the Chelopech gold mine in the area (Fig. 2). Our detailed studies in the eastern and central parts of the basin clearly show the evident lack of structures indicative of wrench tectonics. To the SSW, the basin is bordered by a system of relatively steep to almost vertical, N-vergent, reverse faults, part of the Bunovo-Anton fault zone, which can be followed along the southern slopes of the Stara Planina Mountain between Bunovo and Anton (Figs 4, 6; Dotseva et al., 2016). The zone follows the trace of the Variscan ductile Stargel-Boluvanya shear zone, separating the low- and high-grade metamorphic rocks of the pre-Alpine basement, and is strongly overprinted by the normal fault system bordering the Neogene-Quaternary Zlatitsa Basin (Zlatitsa graben normal fault; Gerdjikov et al., 2017), which testifies to repeated reactivations (Fig. 4). The movements along the Bunovo-Anton fault zone led to the formation of a fault-propagation fold where 
the backlimb is not preserved due to exhumation and the subsequent erosion along the hanging wall (Fig. 6). Although partially destroyed, the forelimb represents a vertical to overturned southern limb of the footwall Chelopech syncline (Fig. 6). Along the SSW border of the basin, the Bunovo-Anton fault zone represents a $\leq 1 \mathrm{~km}$ wide zone including several generally NNE-vergent reverse faults, where some opposite-vergent secondary structures were also observed. Between Mirkovo and Chelopech, the main structure, along which the basement rocks are thrust onto the basin sediments, is covered by the Quaternary sediments, where the sub-thrust zone composed of several reverse faults, cutting through the sediments, is well exposed (Figs 4, 6; Dotseva et al., 2016). In the area of Chelopech, along the SE border of the basin, the Bunovo-Anton fault zone is SW-NE oriented. Here, the main structure is also covered by Quaternary sediments and several SE-vergent reverse faults, together with the NW ones, are also observed (Fig. 4). This bending of the zone is still not well understood. Antonov and Jelev (2001) reported interfering structures in the area of Chelopech, suggesting that the NW-vergent reverse faults (Chelopech duplex) postdate the NNE vergent ones. The authors advocate that the SW-NE trending reverse faults, from the SE margin of the basin, were formed during a later transpressional stage. Such a scenario remains unrealistic because there is no evidence either for the required reactivation of the WNW-ESE trending reverse faults from the SSW border of the basin as strike-slip faults or for the existence of such faults along the opposite NNE margin.

The sediments in the basin are folded generally in a WNW-ESE orientation in the central part, and NE-SW in the eastern part of the basin folds, parallel to the bordering reverse faults (Figs 4, 6). Oblique structures, typical of transpression, are absent. Therefore, it is clearly established that the main structures relating to the deformation of the basin are incompatible with wrench tectonics.

Structures that have eventually been related to the wrench tectonics scenarios are the faults measured in the Chelopech underground mine (e.g., Popov and Popov, 2000; Jelev et al. 2003; Chambefort and Moritz, 2006). Based on detailed structural mapping and drill-core descriptions, three fault populations ( N55-, N110-, and N155-trending faults) have been recognised (e.g., Antonov and Moev, 1978). It is widely accepted that hydrothermal alteration and the ore body geometry at the Chelopech mine are controlled by the $\sim$ N55- and $\sim \mathrm{N} 110$-trending faults, and therefore it was supposed that all three fault sets were formed before the beginning of the compression and the final closure of the basin (Antonov and Moev, 1978; Popov and Popov, 2000; Jelev et al. 2003; Chambefort and Moritz, 2006). However, it must be noted that the character and sense of movement of these faults are usually not reported (e.g., Dobrev and Kuzmanova, 2015). The research of Chambefort and Moritz (2006) is the only study where some information on the character of these faults is presented. The generally NEtrending structures are described as $\sim$ N20- to N55orientated and approximately dipping at $40^{\circ}$ to $50^{\circ}$ to the SE thrusts or reverse faults. The E-W oriented structures are described as N90- to N110-trending and subvertical to $60^{\circ}$ dipping to the south dextral strike-slip faults, and finally the SE-trending structures are described as $\sim \mathrm{N} 135$ - to N170-trending, mainly sub-vertical, strike-slip faults. The authors admit that the relative fault chronology is difficult to determine but suggest that the SE-trending strikeslip faults have served as tear faults between different segments of the NE-oriented thrust and reverse faults. The E-W trending strike-slip faults are described as pre-dating the tear faults. We confirm the existence, also on the surface, of the NE-oriented reverse and SE-trending strike-slip faults and their relationships as described above (Fig. 4).

However, we consider as unrealistic the evolutionary model of Chambefort and Moritz (2006) made on the basis of the above-mentioned structural observations and evoking transtension-transpressional evolution. It is based on data from a relatively restricted area of the mine, which additionally contradict the recent 3D computer modeling of Dobrev and Kuzmanova (2015) based also on underground fault measurements. Secondly, the model does not take into account the tectonic structures from the central and western parts of the basin, which are very different from those in the east. Thirdly, it presents non-existent structures as NE-SW trending normal faults controlling the opening of the basin as well as major E-W trending strike-slip faults bordering it. The non-existence of such fault sets is confirmed not only by our own field data, but also by recent remapping of the area (Antonov et al., 2010).

Our observations from the central part of the basin prove the existence of at least two sets, one $\mathrm{E}-\mathrm{W}$ and the other roughly N-S trending, mainly dextral, strike-slip faults together with the generally WNW-ESE oriented reverse faults. The $\sim \mathrm{N}-\mathrm{S}$ strike-slip faults could be related to the thrusting (acting as tear faults) in the same way as the NW-SE trending strike-slip faults from the Chelopech area (Fig. 4). The tectonic conditions, as well as the time of formation of subequatorial set of strike-slip faults, remain still unclear. 


\section{Panagyurishte Basin}

Up to now, there is no single publication discussing the strike-slip tectonics in this basin. Ivanov (1998, 2017) reinterpreted the main tectonic zones related to the deformation of the basin as dextral strike-slip faults without presenting any supporting evidence.

Our studies in the area, together with examination of the published maps and papers, do not give any evidence of significant wrench tectonics in the basin (e.g., Karagyuleva et al., 1974; Iliev and Katskov, 1990; Gerdjikov et al., 2019). The deformation of the basin fill is related to formation of several NW-SE trending, SW dipping, steep thrusts, virtually representing reverse faults, along which part of the basement has been exhumed (Figs 5, 7). Regional-scale deformation of the footwall sediments is characterized by formation of semi-penetrative structures as decimeter-scale imbricates, striated shear planes and mostly NW-SE oriented folds (Fig. 8a; Gerdjikov et al., 2019, in press). It is also important to note that no oblique structures are observed in the basin and the main anti- and synclines are NW-SE trending, parallel to the main reverse faults (e.g., Karagyuleva et al., 1974; Iliev and Katskov, 1990; Gerdjikov et al., in press; Figs $5,7)$. As in the Chelopech Basin, the maximum displacement is focused along its SW border, where crystalline basement is exhumed (Figs 5, 7). Along the NE margin, the sediments preserve its transgressive contact, which remains mainly unfaulted (Fig. 5). As it was mentioned in the previous chapter, some of the reverse faults present characteristics of inverted normal faults (Fig. 7).

The basin is bordered to the SW by the Kamenitsa-Rakovitsa fault zone, comprising NE-vergent reverse faults (Figs 5, 7; Karagyuleva et al., 1974; Gerdjikov et al., 2019, in press). Along this zone, Ordovician and Variscan high-grade rocks were thrust onto the Upper Cretaceous sediments (Figs 5, 7). Shear sense indicators, such as calcite fibers, imbricate structures and shallow dipping to the SW shear planes, indicate top-to-the- $\mathrm{N}$ to NE sense of movement (Gerdjikov et al., 2019, in press). Farther to the south, the Panagyurishte Basin is bordered by the Stefanchovski fault (Fig. 5; Karagyuleva et al., 1974), which represents a continuation of the Kamenitsa-Rakovitsa fault zone. To the northeast,
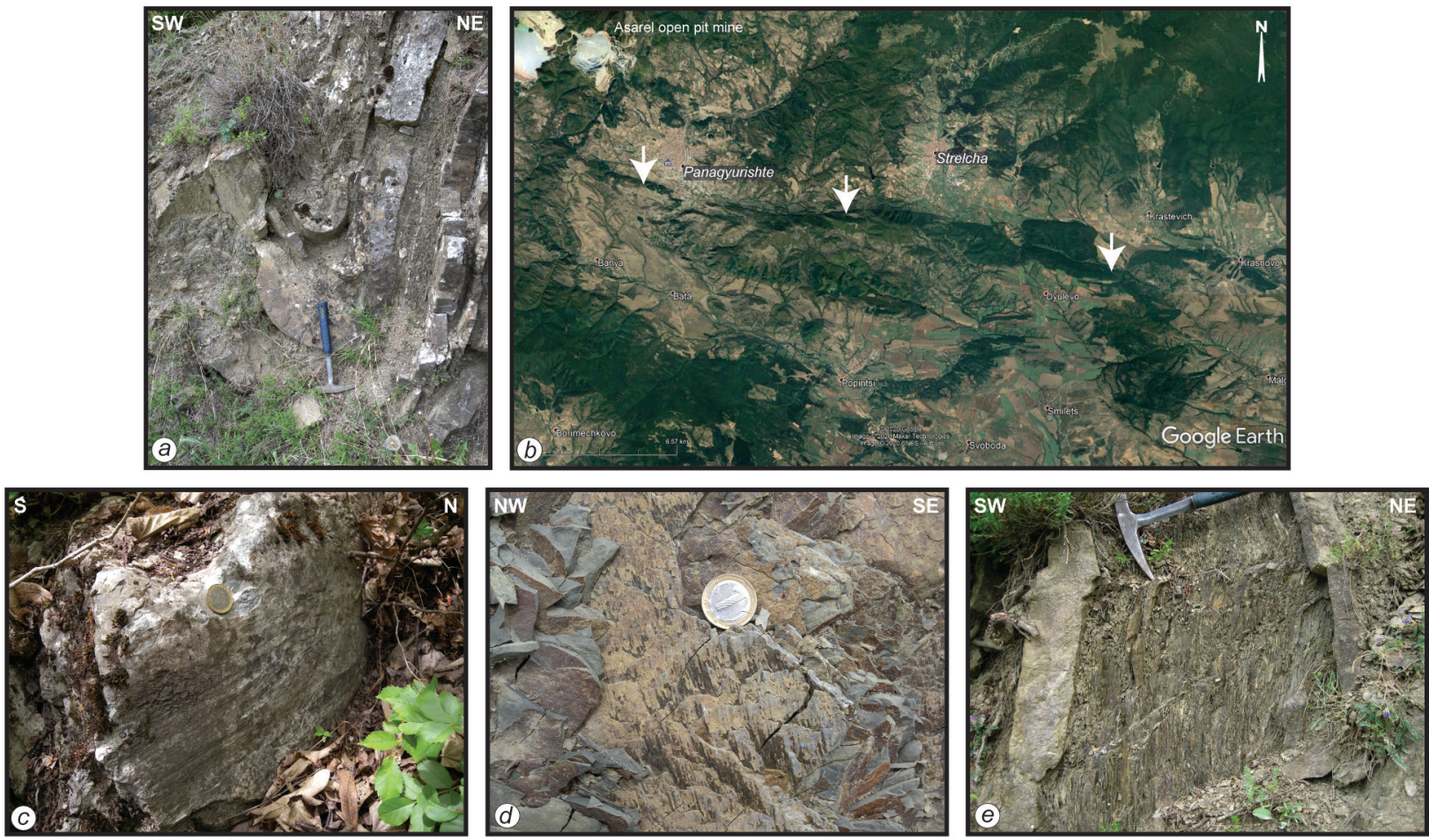

Fig. 8. a) NW-SE oriented meter-scale closed upright fold in the clastic turbidites of the Upper Cretaceous Chugovitsa Formation. b) High-resolution Google Earth image showing the trace of the Panagyurishte fault, well marked on the present-day relief with a notable relative rise of the southwestern block. c) Sub-horizontal striations on the fault plane in the Middle Triassic dolostones along the Petrich fault zone. $d$ ) Steeply-dipping striations on the SW-dipping fault plane in the Upper Cretaceous siltstones of the Chugovitsa Formation along the Petrich fault zone. e) Shallow, dipping to the southwest, synthetic Riedel shears often observed in the soft sediments of the turbiditic Chugovitsa Formation along the steeply dipping in the same direction Petrich fault zone. 
the basin is partially bordered by the Panagyurishte fault, a structure whose character and real extent are not fully clear (Fig. 5). Karagyuleva et al. (1974) described it as a SW-vergent reverse fault, along which the Variscan granites and high-grade metamorphic rocks override the Upper Cretaceous sediments of the basin (Fig. 5). These authors were also the first to report the tectonic contact of the basin sediments with Pliocene-Quaternary sediments, suggesting younger, normal fault movements along the Panagyurishte fault. Such a suggestion is supported by the fact that, unlike the other tectonic structures related to the deformation of the basin, the trace of this fault is well marked on the presentday relief with notable relative rise of the SW block (Fig. 8b). In light of the inversion model for the evolution of the Panagyurishte Basin presented herein, we interpret the Panagyurishte and the situated west of it Krasen faults (Fig. 5) as inverted during the compression extensional structures which controlled the deposition of the Paleogene sediments in the area (Figs 5, 9a, b). Later, the newly formed south-vergent reverse fault was reactivated as a normal fault (Fig. 9c).

The NW part of the Panagyurishte Basin is split into two branches by the Negushevo fault zone, along which hanging wall pre-Cretaceous basement is exhumed (Fig. 5; Bontscheff, 1910). It is now well established that this zone represents a N-NE-vergent compressional fault zone (Gerdjikov et al., 2019).

The logical continuation of the Negushevo fault zone to the SE is the Petrich fault (Figs 5, 7; Karagyuleva et al., 1974; Vangelov et al., 2019; Gerdjikov et al., 2019), which cuts through the sediments of the Panagyurishte Basin in the area of Petrich. Despite having been regarded for long time as an important north-vergent compressional structure (e.g., Karagyuleva et al., 1974), it was later reinterpreted by Ivanov $(1998,2017)$ as a dextral strike-slip zone. Recently, some observations supporting this view were evoked by Balkanska et al. (2018). They cited imbricate fans, contractional duplexes and push-up blocks of Triassic rocks along the fault zone, suggesting dextral strike-slip movement. Although we have observed some sub-horizontal striations (Fig. $8 c$ ), it must be noted that steeply dipping striations are also typical for the fault zone (Fig. 8d). A characteristic of the relatively steeply dipping to the SW Petrich fault zone are also shallow dipping in the same direction synthetic Riedel shears, often observed in the soft sediments of the turbiditic Chugovitsa Formation (Fig. 8e). Therefore, even if we suppose the existence of both dip- and strike-slip movements along this fault, their time and space relationships must be further clearly established.
Finally, we find the reported by Balkanska et al. (2018) horsetail splay termination of the fault as speculative (Fig. 5).

Along the fault planes cutting the Panagyurishte Basin sediments and their basement, we have observed both dip- and oblique-slip striations, showing reverse sense of movement, together with
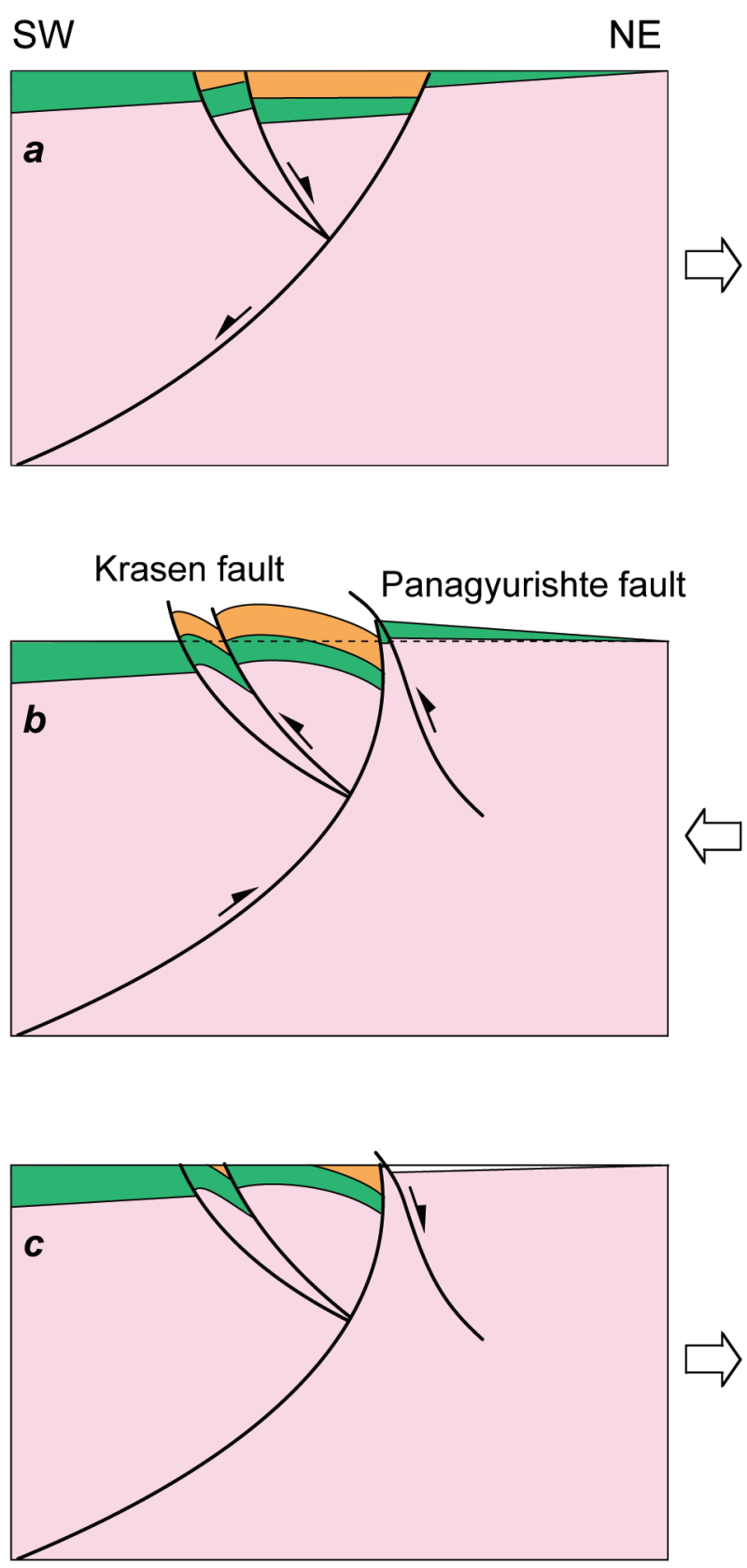

Fig. 9. Evolutionary structural model (not to scale) for the section through the Panagyurishte and Krasen faults, southeast of Panagyurishte (Panagyurishte Basin). The extensional phase, with deposition of Paleogene sediments $(a)$, was followed by a contractional phase and inversion of the extensional structures (b). Later (c), the south-vergent Panagyurishte thrust was reactivated as a normal fault. Lithological key as in Fig. 5. 
sub-horizontal, indicating a mostly dextral sense of shear. The latter are present mainly in the overturned limbs of the footwall synclines (i.e., Kayryaka syncline, Fig. 7) representing single fault planes. The relationships between these two sets of faults are not clear yet and further detailed structural and paleostress studies are necessary. What is important is that NW-SE, as well as other orientation, strike-slip faults, most often cutting the basin sediments, represent only minor tectonic structures without important regional extent. Interesting will be also to investigate further the role of the obliqueslip movements observed along some of the striated planes, as they may be related to transfer faults representing lateral ramps that accommodate differential displacement between adjacent reverse faults.

Therefore, we can conclude that strike-slip movements along fault structures have existed, but they alone cannot produce the amount of exhumation and the deformation patterns characteristic of the Panagyurishte and Chelopech basins. Furthermore, the interpretative cross-sections presented, based on field data and earlier stratigraphic studies, together with the overall tectonosedimentary architecture of the basins, enable us to conclude that the majority of the main tectonic structures are not strike-slip faults but reverse faults, which were controlled by pre-existing extensional structures. All the major reverse faults in both basins are NNE to NE (some NW in the case of the Chelopech Basin) vergent, which is clearly incompatible with a positive flower structure that would be expected during the inversion related to strike-slip tectonics. Additionally, the relative chronology of the strike-slip movements is also not established yet. It is important to note that a regional middle Oligocene-middle Miocene tectonic event, related to predominantly dextral strike-slip faulting, has been reported almost from the entire Balkan Peninsula, including the Maritsa fault zone (e.g., Perinçek, 1991; Zagorchev, 1996; Dumurdzanov et al., 2005; Burchfiel et al., 2008; Kounov et al., 2011; Gerdjikov et al., 2015; Vangelov et al., 2016; Kounov et al., 2018; Mladenović et al., 2019). Therefore, observed within the deformed sediments of the basins and their borders NW-SE trending strike-slip faults may represent a distinct structural overprint, having nothing in common with the major Late Alpine compressional event.

\section{THE PROBLEM OF THE OBLIQUE SUBDUCTION}

It is difficult to say where the proposal of connecting the wrench tectonics in the Sredna Gora Zone with the oblique northward subduction of the Neotethys Ocean below Europe during the Late Cretaceous began (e.g., von Quadt et al., 2005; Chambefort and Moritz, 2006; Georgiev et al., 2009, Naydenov et al., 2013). Gerdjikov and Georgiev (2006b) relate the strike-slip movements along the Maritsa fault zone with the oblique convergence between Africa and Europe in Cretaceous and Cenozoic times, suggested by the paleogeographic reconstructions (Dercourt et al., 1986; Le Pichon et al., 1988).

In more recent plate kinematic reconstructions (e.g., Handy et al., 2014), the northward subduction of the Sava Ocean (part of the Neotethys) in the Late Cretaceous below the NW-SE trending part of the European margin in the Balkan Peninsula also created an oblique convergence. On the other hand, the newly published reconstruction of Hinsbergen et al. (2020) suggests rather orthogonal subduction of the Sava Ocean below Europe in the Balkan Peninsula, during the Cretaceous. However, one may always question the reliability of such reconstructions, because the plate kinematics and absolute vectors used, apart from paleomagnetic data, are based mainly on local structural studies. Other important factors, such as accurate spreading rates and the orientations of the mid ocean ridges and continental margins in the past, are also difficult to constrain.

Therefore, based on the results of local structural studies, we wish to find plausible explanations for the existence of such a long-lived dextral shear zone as the Maritsa shear zone, separating the opposite-vergent thrust belts of the Rhodope to the south and the Sredna Gora and Balkan to the north (Fig. 1).

Below, we present two possible models. First, one considers strain partitioning, as was already suggested by Georgiev et al. (2009), to explain the existence of simultaneous thrusting and strike-slip movements in the Balkanides during the Cretaceous. Studies of active oblique subduction margins, such as the Java-Sumatra subduction system (McCaffrey, 1992, 1996), indicate that the upper crustal deformation may be dominated by margin normal contraction with only localized partitioning into narrow strike-slip fault systems. Similar cases of simultaneous thrusting and strike-slip faulting controlled by oblique crustal convergence have also been reported from the Zagros fold and thrust belt (e.g., Jackson et al., 1995; Talebian and Jackson, 2002; Ruh et al., 2017). This active belt is formed along the boundary of the Arabian and the Iranian plates, where convergence is oblique $\left(\sim 50^{\circ}\right)$. Such scenarios are tested and confirmed 
also by the scaled analogue model of McClay et al. (2004), designed to simulate thrust belt development formed by orthogonal and oblique convergence. Their model, where the convergence vector was oblique at an angle of $45^{\circ}$ to the mar- gin, produced doubly-vergent thrust wedges with thrust faults trending parallel to the margin (Fig. 10). Segmented en-échelon strike-slip faults developed along the axial zone and subordinate oblique-slip motion was observed on some thrust
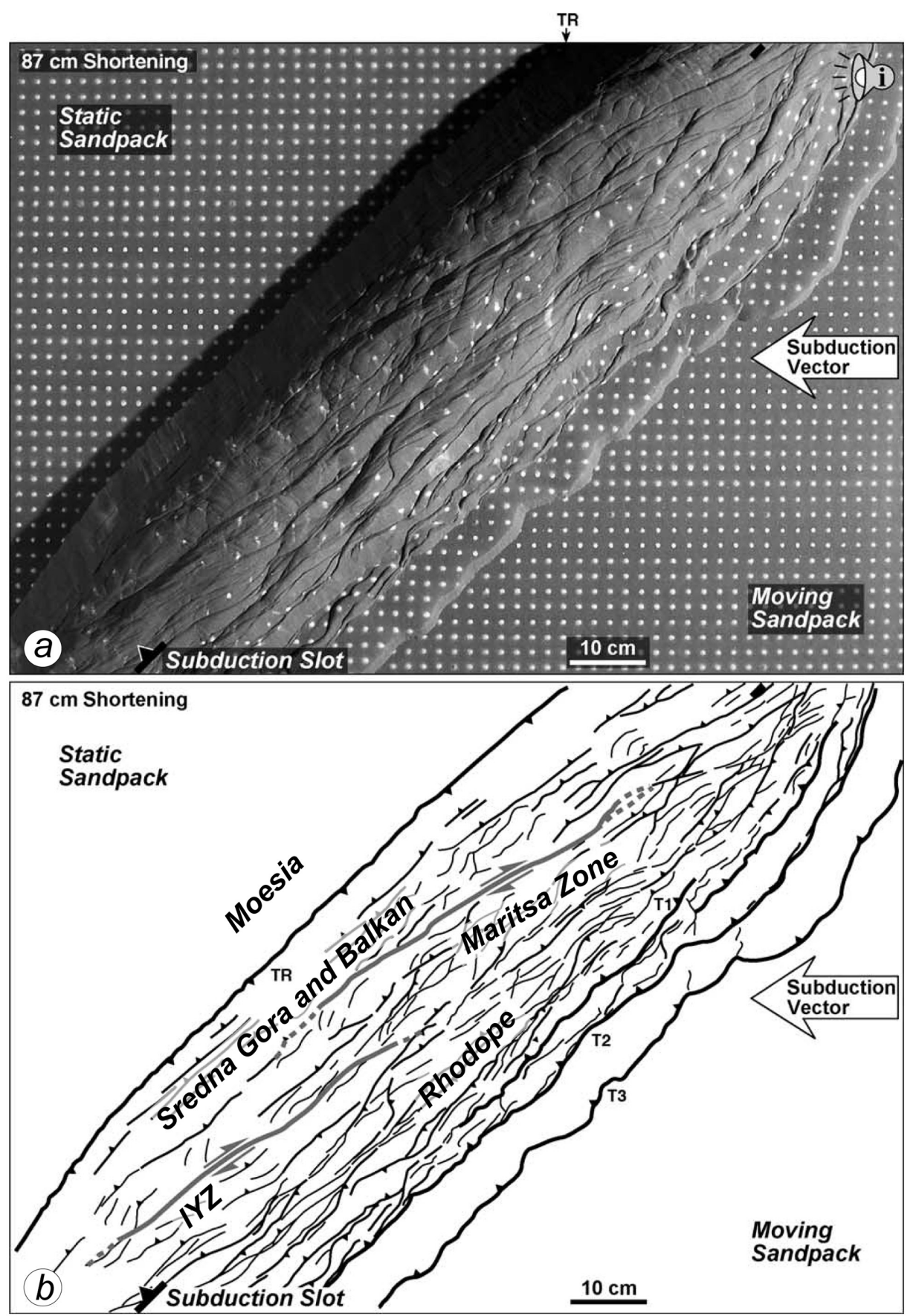

Fig. 10. $45^{\circ}$ Oblique Convergence Model from McClay et al. (2004). (a) Photograph of the end of the model run after $87 \mathrm{~cm}$ of shortening. An asymmetric doubly-vergent wedge system formed parallel to the subduction slot, oblique to the direction of convergence. The retro-wedge on the left-hand side of the model is characterized by closely spaced pro-vergent thrusts that were translated backwards on the main retro-vergent thrust TR. The pro-wedge on the right-hand side of the model consists of a fan of three major pro-vergent imbricate thrusts and associated minor back-thrusts. Segmented en-échelon strike-slip faults cut through the uplifted axial zone of the model. The sequence of thrust nucleation is indicated as T1 to T3 in time; (b) Line diagram interpretation of (a), showing the main retro-vergent thrust TR, the uplifted central core above the subduction slot, and the pro-wedge formed by the three main pro-vergent imbricate thrusts T1-T3. IYZ - Iskar-Yavoritsa Zone. 
faults. This model replicates almost perfectly the real situation in the Balkanides, where the dextral Maritsa fault zone separates the pro-wedge southvergent Rhodope thrust complex from the retrowedge north-vergent Sredna Gora and Balkan foldthrust belt (Fig. 10b). This double wedge of the Balkanide orogen was formed during two distinct compressional phases, called in the Bulgarian literature Early and Late Alpine. The first phase is related to the arrival, in the subduction zone, of the Drama continental fragment in the Late Jurassic (Ricou et al., 1998), hampering the subduction and creating compression in the upper plate. This stage must have continued until the end of the Early Cretaceous, as evidenced by the first signs of post-orogenic extension (e.g., Schmid et al., 2008; Kounov et al., 2010; Antić et al., 2016). This extension obviously led to substantial erosion of the orogen, as is demonstrated by the marine transgression in Cenomanian to Turonian times (e.g., Schmid et al., 2008; Ivanov, 2017). From the Turonian onward, the continuing extension was probably controlled by roll-back of the subducting slab, inducing the formation of the Sredna Gora magmatic belt and basin(s) (e.g., von Quadt et al., 2005). The renewal of the compression at the end of the Cretaceous (Late Alpine phase) is related to the closure of the Sava branch of the Neotethys Ocean and the beginning of the collision between Pelagonia and Europe (e.g., Ricou et al., 1998; Schmid et al., 2008). Therefore, as we have seen from the analogous model presented above and from natural examples of fold-and-thrust belt systems, as well as the field evidence from the Sredna Gora and the neighboring tectonic zone, wrench tectonics may have been focused during the whole Alpine evolution only along the single linear or en-échelon strike-slip zone (Maritsa shear zone) accommodating the strain partitioning created by an oblique convergence. Variations in the angle of the oblique subduction or some other processes could change the importance and the extent of the wrench tectonics.

The second model takes into account the existence of penetrative, NW-SE trending, Variscan fabric in the Sredna Gora basement rocks, favorably oriented to accommodate strike-slip translations along the Maritsa shear zone. In this case, even if we consider that the convergence was rather orthogonal as suggested by some plate kinematic reconstructions (e.g., Hinsbergen et al., 2020), taking also into account the suggestion by several studies of northward relative motion of Africa against Eurasia since the Campanian (Le Pichon et al., 1988; Handy et al., 2010), strike-slip movements could be exclusively produced on these primarily obliquely oriented shear zones or other anisotropies.

\section{CONCLUDING REMARKS}

It is important to emphasize several points. First, both the Chelopech and the Panagyurishte Basin do not present any of the major features typical for pull-apart basins closed during an active transpressive tectonics. All evidence suggests that the compression in the basins was related to inversion tectonics, where pre-existing normal faults were reactivated as steep reverse faults. On the other hand, the presence of strike-slip structures cutting their sediments is evident and the time of their activity and role in the deformation of the basin fill is yet to be revealed.

There is no major evidence for activity during the Late Cretaceous along major strike-slip structures in the central part of Sredna Gora or the neighboring zones other than the Maritsa fault zone. Natural examples from other orogens, supported by analogous modeling, clearly show that, during the oblique convergence, the strain partitioning could be localized along single linear or en-échelon strike-slip zone separating two opposite-vergent thrust belts.

We would like to take this opportunity to appeal to our colleagues to avoid repeating unconfirmed statements and ideas that are not supported by hard evidence. The sad reality is that, if the principle of always citing only well-supported statements published in double-reviewed publications had been maintained, none of these ideas would have gained any real acceptance.

Finally, it is not surprising that the person, through whom everything started, Prof. Zhivko Ivanov, did not publish officially a single line supporting the wrench tectonics concept for the evolution of the Sredna Gora Zone. His Tectonics of Bulgaria was published only posthumously. He was a man of big ideas and had obviously realized that he had not yet fully resolved this one.

\section{Acknowledgements}

We are very thankful to Dian Vangelov for long and fruitful work together in the study area. AK would like to thank Eleonora Balkanska, Stoyan Georgiev and Kalina Georgieva for showing him some beautiful structures in the Panagyurishte Basin. We are grateful to Diane Seward who improved the English. We thank also Lubomir Metodiev, who handled very efficiently the review process, and the reviewer Neven Georgiev for his constructive comments. 


\section{REFERENCES}

Aiello, E., Bartolini, C., Boccaletti, M., Gocev, P., Karagjuleva, J., Kostadinov, V., Manetti, P. 1977. Sedimentary features of the Srednogorie zone (Bulgaria): an Upper Cretaceous intra-arc basin. Sedimentary Geology 19, 39-68.

Angelov, V., Antonov, M., Gerdjikov, S., Petrov, P., Kiselinov, H., Tanatsiev, S., Valev, V. 2010. Geologic Map of the Republic of Bulgaria in scale 1:50 000, Etropole map sheet. Ministry of Environment and Water, Bulgarian National Geological Survey, Sofia (in Bulgarian).

Antić, M.D., Kounov, A., Trivić. B., Wetzel, A., Peytcheva, I., von Quadt, A. 2016. Alpine thermal events in the central Serbo-Macedonian Massif (south-eastern Serbia). International Journal of Earth Sciences 105, 1485-1505.

Antonov, M. 1976. Structure of the Etropole Nappe. Review of the Bulgarian Geological Society 37 (1), 37-48.

Antonov, M., Moev, M. 1978. Structure of the Eastern part of the Sturgel-Chelopech strip. Annual of the University of Mining and Geology 23, 31-50 (in Bulgarian).

Antonov, M., Jelev, V. 2001. Transpression and oblique fold and thrust structures in Chelopech ore field (Bulgaria). Annual of the University of Mining and Geology 43-44, 45-49.

Antonov, M., Jelev, V. 2002. Ductile shear zone and brittle faults in the southwestern slope of Zlatitsa-Teteven mountain (Central Bulgaria). Annual of the University of Mining and Geology 45, 13-20.

Antonov, M., Gerdjikov, S. Metodiev, L., Kiselinov, H., Sirakov, V., Valev, V. 2010. Explanatory note to the Geological Map of the Republic of Bulgaria in Scale 1:50 000, Pirdop map sheet. Ministry of Environment and Water, Bulgarian National Geological Survey, Sofia, 39-47 (in Bulgarian).

Balkanska, E., Vangelov, D., Georgiev, S. 2018. Post-magmatic (ore) transpressive deformation, controlling the closure of the Late Cretaceous basin - a case study from the Panagyurishte strip, Central Srednogorie Zone, Bulgaria. XXI International Congress of the CBGA, Salzburg, Austria, Abstract volume, 10-13.

Bergerat, F., Vangelov, D., Dimov, D. 2010. Brittle deformation, paleostress field reconstruction and tectonic evolution of the Eastern Balkanides (Bulgaria) during Mezozoic and Cenozoic times. In: Sosson, M., Kaymakci, N., Stephenson, R.A., Bergerat, F., Starostenko, V. (Eds), Sedimentary Basin Tectonics from the Black Sea and Caucasus to the Arabian Platform. Geological Society, London, Special Publications 340, 77-111.

Boccaletti, M., Manetti, P., Peccerillo, A. 1974. The Balkanides as an instance of back-arc thrust belt: Possible relation with the Hellenides. Geological Society of America Bulletin 85, 1077-1084.

Bončev, E. 1940. Über die Geologie des Bajlovo Teiles der Panagjuriste-Zone der Srednogorie unter Berücksichtigung der Tektonik dieser Zone. Review of the Bulgarian Geological Society 11, 205-238 (in Bulgarian, with German abstract).

Boncev, E. 1946. Basiques de la tectonique de la Bulgarie. Annuaire de la Direction pour des Recherches géologiques et minières en Bulgarie 4, 336-379 (in Bulgarian, with French abstract).

Bončev, E. 1961. Notizen über die Wichtigsten Bruchlinien im Bulgarien. Travaux sur la Géologie de Bulgarie, Stratigraphie et Tectonique 2, 5-29 (in Bulgarian, with German abstract).

Bonev, K. 1996. Limite NW du massif cristallin Rhodopien. Relations avec le domaine des Balkanides. Mémoires des
Sciences de la Terre, Université Pierre et Marie Curie, Paris, $277 \mathrm{pp}$.

Bontscheff, S. 1910. Die Leitlinien der Geologischen Bau des Westlichen Balkans. Travaux de la Société bulgare des sciences naturelles 4, 1-59 (in Bulgarian, with German abstract).

Boyadjiev, S. 1971. Maritza deep fault. In: Yovchev, Y. (Ed.), Tectonic structure of Bulgaria, Tehnika, Sofia, 24-431.

Boyanov, I., Iossifov, D. 1983. The Maritsa fault and the Late and Post Alpine strike-slip movements connected with it. In: Boyanov, I., Kostadinov, V., Iossifov, D., Bonchev, E. (Eds), Maritsa Fault and Block-Structure of the Bulgarian Srednogorie Zone. International Cooperation Commission IX ANSS, 34-43 (in Russian).

Burchfiel, B.C., Nakov, R., Dumurdžanov, N., Papanikolaou, D., Tzankov, T., Serafimovski, T., King, R.W., Kotzev, V., Todosov, A., Nurce, B. 2008. Evolution and dynamics of the Cenozoic tectonics of the South Balkan extensional system. Geosphere 4, 919-938.

Burg, J-P. 2011. Rhodope: from Mesozoic convergence to Cenozoic extension. Review of petro-structural data in the geochronological frame. Journal of Virtual Explorer 42, $1-44$.

Chambefort, I., Moritz, R. 2006. Late Cretaceous structural control and Alpine overprint of the high-sulfidation $\mathrm{Cu}-$ $\mathrm{Au}$ epithermal Chelopech deposit, within the geodynamic setting of the Panagyurishte region, Srednogorie belt, Bulgaria. Mineralium Deposita 41, 259-280.

Cotesta, L. 2015. Geomechanical framework model for the Ellatzite open pit. Report to Ellatzite-Med AB, 31 pp.

Dabovski, C. 1969. Some general regularities in the structure of the neoplutonic bodies from the southern margin of the Srednogorie Zone between the towns of Sofia and Plovdiv. Bulletin of the Geological Institute, Bulgarian Academy of Sciences, Series Geotectonics 8, 61-72 (in Bulgarian).

Dabovski, H., Sinnyovsky, D., Vasilev, E., Dimitrova, E. 2009. Upper Cretaceous geology - Stratigraphy. In: Zagorchev, I., Dabovski, C., Nikolov, T. (Eds.), Geology of Bulgaria. Volume II. Mesozoic geology. "Prof. Marin Drinov" Academic Publishing House, Sofia, 15-37.

Dercourt, J., Zonenshain, L.P., Ricou, L.-E., Kazmin, V.G., Le Pichon, X., Knipper, A.L., Grandjacquet, C., Sbortshikov, I.M., Geyssant, J., Lepvrier, C., Pechersky, D.H., Boulin, J., Sibuet, J.-C., Savostin, L.A., Sorokhtin, O., Westphal, M., Bazhenov, M.L., Lauer, J.P., Biju-Duval, B. 1986. Geological evolution of the Tethys belt from the Atlantic to the Pamirs since the Lias. In: Aubouin, J., Le Pichon, X., Monin A.S. (Eds), Evolution of the Tethys. Tectonophysics 123, 241-315.

Dimitrov, S. 1937. Notizen über die Geologie und Petrographie der Lozenska Planina (Bulgarien). Annual of Sofia University 1 (3), 163-218.

Dobrev, M., Kuzmanova, P. 2015. Fault zones in west part of Chelopech deposit. Annual of the University of Mining and Geology 58, 99-106.

Doglioni, C., Busatta, C., Bolis, G., Mariannini, L., Zanella, M. 1996. Structural evolution of the Eastern Balkans (Bulgaria). Marine and Petroleum Geology 13(2), 225-251.

Dotseva, Z., Vangelov, D., Gerdzhikov, I., Dancheva, D. 2016. Bunovo-Anton Fault Zone -an array of fault segments or remnants of a Late Alpine fault zone?. Bulgarian Geological Society, National Conference with International Participation “Geosciences 2016”, Abstracts, 87-88.

Drew, L.J. 2005. A tectonic model for the spatial occurrence of porphyry copper and polymetallic vein deposits - Applica- 
tions to central Europe. U.S. Geological Survey Scientific Investigations Report 2005-5272, 36 pp.

Dumurdzanov, N., Serafimovski, T., Burchfiel, B.C. 2005. Cenozoic tectonics of Macedonia and its relation to the South Balkan extensional regime. Geosphere 1, 1-22.

Gallhofer, D., Quadt, A., Peytcheva, I., Schmid, S., Heinrich, A.C. 2015. Tectonic, magmatic and metallogenic evolution of the Late Cretaceous Arc in the Carpathian-Balkan orogen. Tectonics 34, 1813-1836.

Georgiev, G. 2004. Geology of porphyry copper deposit Elatsite, Bulgaria. Annual of the University of Mining and Geology, Geology and Geophysics 47 (1), 75-82 (in Bulgarian, with English abstract).

Georgiev, G. 2008. A genetic model of the Elatsite porphyry copper deposit, Bulgaria. Geochemistry, Mineralogy and Petrology 46, 143-160.

Georgiev, N., Henry, B., Jordanova, N., Froitzheim, N., Jordanova, D., Ivanov, Z., Dimov, D., 2009. Emplacement mode of Late Cretaceous plutons from the southwestern part of Sredna Gora zone, Bulgaria: structural and AMS study. Geologica Carpathica 60, 15-33.

Georgiev, N., Henry, B., Jordanova, N., Jordanova, D., Naydenov, K. 2014. Emplacement and fabric-forming conditions of plutons from structural and magnetic fabric analysis: A case study of the Plana pluton (Central Bulgaria). Tectonophysics 629 (26), 138-154.

Gerdjikov, I., Georgiev, N. 2005. Spectacular fabric but little displacement: Early Alpine shear zone from Zlatishka Stara Planina, Central Balkanides. Bulgarian Geological Society, Jubilee Conference with International Participation, "80 years Bulgarian Geological Society", Abstracts, $35-38$.

Gerdjikov, I., Georgiev, N., 2006a. The Svishti Plaz Allochthon (Central Balkanides). Position and associated fabric. Comptes Rendus de l'Académie bulgare des Sciences 59 (6), 631-638.

Gerdjikov, I., Georgiev, N. 2006b. The Maritsa fault system - a strike-slip zone along the northern margin of the Rhodopes. Annual of the University of Mining and Geology 49 (1), 33-39 (in Bulgarian, with English abstract).

Gerdjikov, I., Radulov, A., Metodiev, L. 2015. Cretaceous-Tertiary deformations along a part of the Maritsa fault system between Pazardzhik and Sofia. Bulgarian Geological Society, National Conference with International Participation “Geosciences 2015”, Abstracts, 89-90.

Gerdjikov, I., Dotseva, Z., Vangelov, D. 2017. Extensional reactivation of former compressional fault zone: An example from eastern part of Zlatitsa graben. Annual of the University of Mining and Geology 69 (1), 122-127.

Gerdjikov, I., Vangelov, D., Kounov, A. 2019. Main fault zones controlling the late Alpine structure in the area east of Sofia (Srednogorie Zone, Western Bulgaria). Journal of Mining and Geological Sciences 62, 71-76.

Gerdjikov, I., Dinev, Y., Vangelov, D. (in press). Structural geology of the central part of Kamenitsa-Rakovishka fault zone. Journal of Mining and Geological Sciences. University of Mining and Geology "St. Ivan Rilski”.

Gürbüz, A. 2010. Geometric characteristics of pull-apart basins. Lithosphere 2 (3), 199-206.

Handler, R., Neubauer, F., Velichkova, S., Ivanov, Z. 2004. 40Ar/39Ar age constraints on the timing of magmatism in the Panagyurishte region, Bulgaria. Schweizerische Mineralogische und Petrographische Mitteilungen 84, 119-132.

Handy, M.R., Schmid, S.M., Bousquet, R., Kissling, E., Bernoulli, D. 2010. Reconciling plate-tectonic reconstructions of Alpine Tethys with the geological and geophysical re- cord of spreading and subduction in the Alps. Earth-Science Reviews 102, 121-158.

Handy, M.R., Ustaszewski, K., Kissling, E., 2015. Reconstructing the Alps-Carpathians-Dinarides as a key to understanding switches in subduction polarity, slab gaps and surface motion. International Journal of Earth Sciences 104, 1-26.

Hempton, M.R., and Dunne, L.A., 1984. Sedimentation in pullapart basins: Active example in eastern Turkey. The Journal of Geology 92, 513-530.

Henry, B., Naydenov, K., Dimov, D., Jordanova, D., Jordanova, N. 2012. Relations between the emplacement and fabric-forming conditions of the Kapitan-Dimitrievo pluton and the Maritsa shear zone (Central Bulgaria): magnetic and visible fabrics analysis. International Journal of Earth Sciences 101, 747-749.

Iliev, K., Katskov, N. 1990. Geological Map of the People's Republic of Bulgaria in scale 1:100 000, Panagyurishte map sheet. Committee of Geology, Sofia (in Bulgarian).

Ivanov, Ž. 1998. Tectonics of Bulgaria. Professorship thesis, Sofia University “St Kliment Ohridski”, 579 pp. (in Bulgarian, unpublished)

Ivanov, Ž. 2017. Tectonics of Bulgaria. Sofia University Press, Sofia, 331 pp. (in Bulgarian).

Ivanov, Z., Dimov, D. 2002. Structure and tectonic evolution of the Panagyurishte Upper Cretaceous strip. GEODE Workshop on the Srednogorie zone, Abstract volume, Sofia, 8-8.

Ivanov, Z., Dimov, D. Sarov, S., Mishev, E. 1989. Structure and tectonic evolution of the central parts of the Rhodope massif. Travel Guide of the Excursions E-3, XIV Congress of KBGA, Sofia, 91-102 (in Russian).

Ivanov, Z., Henry, B., Dimov, D., Georgiev, N., Jordanova, D., Jordanova, N. 2001. New model for Upper Cretaceous magma emplacement in the southwestern parts of Central Srednogorie - Petrostructural and AMS data. ABCDGEODE 2001 Workshop, Geodynamics and ore deposit evolution of the Alpine-Balkan-Carpathian-Dinaride Province, Vaţa Băi, Romania, 8-12 June 2001, Romanian Journal of Mineral Deposits, Special Volume 79(2), 60-61.

Ivanov, Z., Georgiev, N., Lazarova, A., Dimov, D. 2002. New model of Upper Cretaceous magma emplacement in the southwestern parts of Central Sredna Gora zone, Bulgaria. Geologica Carpathica 53, Special issue, Proceedings of the XVII Congress of CBGA, Bratislava, 5 pp.

Ivanov, Z., Petrov, N., Lazarova, A., Uzunov, D., Nedkova, K., Georgiev, N., Dimov, D., Naidenov, K., Nikolov, D. 2004. Structure of the Elatsite copper mine. Unpublished report of Sofia University, 74 pp. (in Bulgarian).

Jackson, J.A., Haines, J., Holt, W. 1995. The accommodation of the Arabian-Eurasia plate convergence in Iran. Journal of Geophysical Research 100, 15205-15219.

Jelev, V., Antonov, M., Arizanov, A., Arnaudova, R. 2003. On the genetic model of Chelopech volcanic structure (Bulgaria). Annual of the University of Mining and Geology "St Ivan Rilski” 46, 47-51.

Karagyuleva, J., Kostadinov, V., Tsankov, T., Gochev, P. 1974. Composition of the Pangyuriste strip east of the Topolnitsa River. Bulletin of the Geological Institute, Bulgarian Academy of Sciences, Series Geotectonics 23, 231-301 (in Bulgarian).

Kouikin, S., Milanov, L., Gercheva, Y., Christov, S. 1971. Geological structure of Stara Planina between Zlatitsa pass and Troyan pass. Bulletin of the Committee of Geology 18, 179-200 (In Bulgarian).

Kounov, A., Seward, D., Burg, J-.P., Bernoulli, D., Ivanov, Z., Handler, R. 2010. Geochronological and structural constraints on the Cretaceous thermotectonic evolution of the Kraishte zone (Western Bulgaria). Tectonics 29 (doi:10.1029/2009TC002509). 
Kounov, A., Burg, J.-P., Bernoulli, D., Seward, D., Ivanov, Z., Dimov, D., Gerdjikov, I. 2011. Paleostress analysis of Cenozoic faulting in the Kraishte area, SW Bulgaria. Journal of Structural Geology 33, 859-874.

Kounov, A., Gerdjikov, I., Vangelov, D., Balkanska, E., Lazarova, A., Georgiev, S., Stockli, D., Blunt, E. 2018. First thermochronological constraints on the Cenozoic extension along the Balkan Fold-Thrust Belt (Central Stara Planina Mountain, Bulgaria). International Journal of Earth Sciences 107 (4), 1515-1535.

Lazarova, A., Gerdjikov, I., Georgiev, N., Dimov, D. 2006. The Anton shear zone (Central Stara planina Mountains). Temporal relations, extent and significance. Comptes rendus de l'Académie bulgare des Sciences 59 (6), 639-644.

Le Pichon, X., Bergerat, F., Roulet, M.J. 1988. Plate kinematics and tectonics leading to the Alpine belt formation: A new analysis. In: Clark, S.P., Burchfiel, B.C., Suppe, J. (Eds), Processes in Continental Lithospheric Deformation. Geological Society of America, Special Paper 218, 111-131.

McCaffrey, R. 1992. Oblique plate convergence, slip vectors, and forearc deformation. Journal of Geophysical Research 97, 8905-8915.

McCaffrey, R. 1996. Slip partitioning at convergent plate boundaries of SE Asia. In: Hall, R., Blundell, D. (Eds), Tectonic evolution of South East Asia. Geological Society of London, Special Publication 106, 3-18.

McClay, K.R., Whitehouse, P.S., Dooley, T., Richards, M. 2004. 3D evolution of fold and thrust belts formed by oblique convergence. Marine and Petroleum Geology 21, 857-877.

Mladenović, A., Antić, M.D., Trivić, B., Cvetković, V. 2019. Investigating distant effects of the Moesian promontory: brittle tectonics along the western boundary of the Getic unit (East Serbia). Swiss Journal of Geosciences 112 (1), 143-161.

Nachev, I.K. 1978. On the Upper Cretaceous basin model in the Srednogorie zone. Comptes rendus de l'Académie bulgare des Sciences 31 (2), 213-216.

Naydenov, K., Peytcheva, I., von Quadt, A., Sarov, S., Kolcheva, K., Dimov, D. 2013. The Maritsa strike-slip shear zone between Kostenets and Krichim towns, South Bulgaria Structural, petrographic and isotope geochronology study. Tectonophysics 595-596, 69-89.

Nilson, T.H., Sylvester, A.G. 1995. Strike-slip basins. In: Busby, C., Ingersoll, R.V. (Eds), Tectonics of Sedimentary Basins. Blackwell Science, Cambridge, Massachusetts, USA, 425-455.

Nanov, Z., Naydenov, K., Georgiev, N., Lazarova, A. 2018. Polyphase Variscan and Alpine Tectonic History of a Paleozoic Greenschist Basement of Central Stara Planina, Bulgaria. In: Šujan, M., Csibri, T., Kiss, P., Rybár, S. (Eds), Environmental, Structural and Stratigraphical Evolution of the Western Carpathians. $11^{\text {th }}$ ESSEWECA Conference, Abstract Book, Bratislava, Slovakia, 75-76.

Noda, A. 2013. Strike-slip basin-its configuration and sedimentary facies. In: Itoh, Y. (Ed). Mechanism of Sedimentary Basin Formation. InTech Press, Novi Sad, 27-57

Perinçek, D., Ataş, N., Karatut, Ş., Erensoy, E. 2015. Geological factors controlling potential of lignite beds within the Danişmen Formation in the Thrace Basin. Bulletin of the Mineral Research and Exploration 150, 77-108

Petrov, N. 2005a. Emplacement mechanism of Late Cretaceous subvolcanic magmatic bodies during transpression in the Northern part of Sredna Gora tectonic zone, Bulgaria. Annual of Sofia University 98, 43-65 (in Bulgarian, with English abstract)

Petrov, N. 2005b. Elatsite copper mine - an example of magma emplacement in the local extensional domain of the dextral strike-slip Kashana shear zone. Bulgarian Geological Society, Jubilee Conference with International Participation "80 years Bulgarian Geological Society”, Abstracts, 54-56.

Petrov, N., Nedkova, K. 2011. Internal structure of the Elatsite fault zone. Comptes rendus de l'Académie bulgare des Sciences 64 (8), 1157-1162.

Popov, P., Mutafchiev, I. 1980. Structure of Chelopech copper field. Structural conditions for ore localization. Annual of the University of Mining and Geology 25, 25-41 (in Bulgarian).

Popov, P., Popov, K. 2000. General geologic and metallogenic features of the Panagyurishte ore region. In: Strashimirov, S., Popov, P. (Eds), Geology and Metallogeny of the Panagyurishte ore region (Srednogorie zone, Bulgaria). ABCD-GEODE 2000 Workshop, Guide Book to Excursions, Sofia, 1-7.

Ricou, L-.E, Burg, J-.P., Godfriaux, I., Ivanov, Z. 1998. Rhodope and Vardar: the metamorphic and the olistostromic paired belts related to the Cretaceous subduction under Europe. Geodynamica Acta 11, 285-309.

Rodgers, D.A. 1980. Analysis of pull-apart basin development produced by en echelon strike-slip faults. In: Balance, P.F., Reading, H.G. (Eds), Sedimentation in oblique-slip mobile zones. International Association of Sedimentologists, Special Publications 4, 27-41.

Ruh, J.B., Gerya, T., Burg, J.-P. 2017. Towards 4D modelling of orogenic belts: example from the transpressive Zagros Fold Belt. Tectonophysics 702, 82-89.

Sarov, S., Petrov, N., Voinova, E., Nedkova, K., Naydenov, K., Georgieva, I., Nikolov, D., Kolcheva, K. 2006. Data on strike-slip shearings in the low-grade methamorphic sections (Trachian Unit) in the northern part of the Central Rhodopes. Bulgarian Geological Society, National Conference with International Participation "Geosciences 2006”, Abstracts, 102-105 (in Bulgarian).

Schmid, S.M., Bernoulli, D., Fügenschuh, B., Matenco, l., Schefer, S., Schuster, R., Tichler, M., Ustaszewski, K. 2008. The Alpine-Carpathian-Dinaridic orogenic system: correlation and evolution of tectonic units. Swiss Journal of Geosciences 101, 139-183.

Talebian, M., Jackson, J. 2002. Offset on the Main Recent fault of NW Iran and its implications for the late Cenozoic tectonics of the Arabia-Eurasia collision zone. Geophysical Journal International 150, 422-439.

Twiss, R., Moores, E. 2001. Structural Geology. W.H. Freeman and Company, New York, 532 pp.

Vangelov. D., Kiselinov, H., Andreeva, P., Vangelova, V. 2013. Structural characteristics for a part of the Eastern Fore-Balkan. Review of the Bulgarian Geological Society 74 (1-3), 21-39.

Vangelov, D., Gerdjikov, I., Kounov, A., Lazarova, A. 2013. The Balkan Fold-Thrust Belt: an overview of the main features. Geologica Balcanica 42, 29-47.

Vangelov, D., Pavlova, M., Gerdjikov, I., Kounov, A. 2016. Timok fault and Tertiary strike-slip tectonics in part of western Bulgaria. Annual of the University of Mining and Geology "St Ivan Rilski” 59, 112-117.

Vangelov, D., Gerdjikov, I., Dochev, D., Dotseva, Z., Velev, S., Dinev, Y., Trayanova, D., Dancheva, J. 2019. Upper Cretaceous lithostratigraphy of the Panagyurishte strip (Central Bulgaria) - part of the Late Cretaceous ApuseniBanat-Timok-Srednogorie magmatic belt. Geologica Balcanica 48, 11-33.

van Hinsbergen, D.J.J., Torsvik, T.H., Schmid, S.M., Maţenco, L.C., Maffione, M., Gürer, D., Vissers, R.L.M. 2020. Companion paper. Orogenic architecture of the Mediterranean region and kinematic reconstruction of its tectonic evolution since the Triassic. Gondwana Research 81, 79-229. 
Velichkova, S., Handler, R., Neubauer, F., Ivanov, Z. 2004. Variscan to Alpine tectonothermal evolution of the Central Srednogorie unit, Bulgaria: constraints from ${ }^{40} \mathrm{Ar} /{ }^{39} \mathrm{Ar}$ analysis. Schweizerische Mineralogische und Petrographische Mitteilungen 84, 133-151.

von Quadt, A., Moritz, R., Peytcheva, I., Heinrich, Ch.A. 2005. Geochronology and geodynamics of Late Cretaceous magmatism and $\mathrm{Cu}-\mathrm{Au}$ mineralization in the Panagyurishte region of the Apuseni-Banat-TimokSrednogorie belt, Bulgaria. Ore Geology Reviews 27, 95-126.

Wu, J.E., Mcclay, K., Whitehouse, P., Dooley, T. 2009. 4D analogue modelling of transtensional pull-apart basins. $M a$ rine and Petroleum Geology 26, 1608-1623.
Zagorchev, I. 1996. Pre-Palaeogene Alpine tectonic units and terranes in the border area of SW Bulgaria and Yugoslavia. In: Knezevic, V., Krstic, B. (Eds), Terranes of Serbia. University of Belgrade, Belgrade, 81-86.

Zagorchev, I., Pavlishina, P., Cernjavska, S., Boyanov, I., Goranov, A. 2001. First data on a Danian age of the conglomeratic formation near Panagyurishte and Strelcha (Sredna-Gora Mountains). Comptes rendus de l'Académie bulgare des Sciences 54 (8), 53-56.

Zimmerman, A., Stein, H.J., Hannah, J.L., Kozelj, D., Bogdanov, K., Berza, T. 2008. Tectonic configuration of the Apuseni- Banat-Timok-Srednogorie belt, Balkans-South Carpathians, constrained by high precision Re-Os molybdenite ages. Mineralium Deposita 43, 1-21. 